\title{
OPEN Pyrazoline derivatives as promising novel antischistosomal agents
}

\author{
Cristiane S. Morais ${ }^{1}$, Ana C. Mengarda ${ }^{1}$, Fábio B. Miguel ${ }^{2}$, Karine B. Enes ${ }^{2}$, \\ Vinícius C. Rodrigues ${ }^{1}$, Maria Cristina C. Espírito-Santo ${ }^{3,4}$, Abolghasem Siyadatpanah ${ }^{5}$, \\ Polrat Wilairatana $^{6 \bowtie}$, Mara R. C. Couri ${ }^{2 \bowtie}$ \& Josué de Moraes ${ }^{1 \bowtie}$
}

Praziquantel is the only available drug to treat schistosomiasis, a parasitic disease that currently infects more than $\mathbf{2 4 0}$ million people globally. Due to increasing concerns about resistance and inadequate efficacy there is a need for new therapeutics. In this study, a series of 17 pyrazolines (15-31) and three pyrazoles (32-34) were synthesized and evaluated for their antiparasitic properties against ex vivo adult Schistosoma mansoni worms. Of the 20 compounds tested, six had a $50 \%$ effective concentration ( $\mathrm{EC}_{50}$ ) below $30 \mu \mathrm{M}$. Our best hit, pyrazoline 22, showed promising activity against adult schistosomes, with an $\mathrm{EC}_{50}<10 \mu \mathrm{M}$. Additionally, compound 22 had low cytotoxicity, with selectivity index of $\mathbf{2 1 . 6}$ and $\mathbf{3 2 . 2}$ for monkey and human cell lines, respectively. All active pyrazolines demonstrated a negative effect on schistosome fecundity, with a marked reduction in the number of eggs. Structure-activity relationship analysis showed that the presence of the non-aromatic heterocycle and $\mathrm{N}$-substitution are fundamental to the antischistosomal properties. Pharmacokinetics, drug-likeness and medicinal chemistry friendliness studies were performed, and predicted values demonstrated an excellent drug-likeness profile for pyrazolines as well as an adherence to major pharmaceutical companies' filters. Collectively, this study demonstrates that pyrazoline derivatives are promising scaffolds in the discovery of novel antischistosomal agents.

Schistosomiasis is an infectious disease which leads to significant economic and public health consequences, particularly in the poorest communities. It is a water-associated disease caused by infection with parasitic trematodes of the genus Schistosoma ${ }^{1}$. With an estimated global prevalence of 240 million infected people, schistosomiasis is intimately correlated with poverty, and the disease is associated with a chronic and debilitating morbidity manifested by sequelae such as cognitive impairment, growth stunting, and decreased physical fitness, among other pathological effects ${ }^{2,3}$. Disease pathology is due to immunologic reactions to Schistosoma eggs trapped in tissues, mainly in the liver and spleen ${ }^{1,4}$. Among species that infect humans, Schistosoma mansoni has the widest geographical distribution, being found in Africa, the Middle East, South America and the Caribbean ${ }^{3}$.

The global schistosomiasis control strategy relies upon preventive chemotherapy with praziquantel, via mass drug administration. Estimates show that at least 236.6 million people required preventive treatment with praziquantel in $2019^{3}$. Although the drug is effective against all schistosome species, numerous persistent schistosomiasis hotspots remain ${ }^{5-7}$. In addition, low cure rates and concern with drug resistance have recently been reported $^{8}$. Praziquantel has also been extensively used for the control of platyhelminth parasites in domestic and livestock animals, and populations of animals with flatworm infections that were not eliminated despite multiple treatments with praziquantel have been identified ${ }^{9}$. Since treatment options for flatworm infections are limited in both human and veterinary medicine, there is an urgent need to identify novel antischistosomal agents as an alternative treatment for schistosomiasis and other flatworm infections ${ }^{10,11}$.

In recent years, a significant number of nitrogen heterocycles have been approved by the Food and Drug Administration (FDA) as chemotherapeutic drugs ${ }^{12,13}$. In the search for new antischistosomal agents, studies have been directed towards investigating the schistosomicidal activities of synthetic heterocyclic compounds e.g. ${ }^{14,15}$. Pyrazole, and its reduced form pyrazoline, are the electron-rich nitrogen heterocycles which play an

${ }^{1}$ Research Center for Neglected Diseases, Guarulhos University, Praça Tereza Cristina, 229, Centro, Guarulhos, SP 07023-070, Brazil. 2Department of Chemistry, Federal University of Juiz de Fora, Juiz de Fora, MG 36036-900, Brazil. ${ }^{3}$ Laboratory of Immunopathology of Schistosomiasis (LIM-06), Department of Infectious and Parasitic Diseases, Faculty of Medicine, University of São Paulo, São Paulo, SP, Brazil. "4Laboratory of Helminthology, Institute of Tropical Medicine, University of São Paulo, São Paulo, SP, Brazil. ${ }^{5}$ Ferdows School of Paramedical and Health, Birjand University of Medical Sciences, 9717853577 Birjand, Iran. ${ }^{6}$ Department of Clinical Tropical

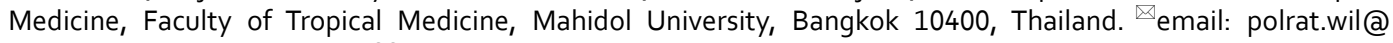
mahidol.ac.th; mara.rubia@uff.edu.br; moraesnpdn@gmail.com 
<smiles>[R7]c1ccc(C(C)=O)cc1</smiles><smiles>[R]c1ccc(/C=C/C(=O)c2ccc([R1])cc2)cc1</smiles>

$(1-14)$
1: $\mathrm{R}_{1}=\mathrm{H} ; \mathrm{R}_{2}=\mathrm{O}\left(\mathrm{CH}_{2}\right)_{3} \mathrm{CH}_{3}(79 \%)$
2: $\mathrm{R}_{1}=\mathrm{H} ; \mathrm{R}_{2}=\mathrm{O}\left(\mathrm{CH}_{2}\right)_{5} \mathrm{CH}_{3}(99 \%)$
3: $\mathrm{R}_{1}=\mathrm{H} ; \mathrm{R}_{2}=\mathrm{O}\left(\mathrm{CH}_{2}\right)_{7} \mathrm{CH}_{3}(95 \%)$
4: $\mathrm{R}_{1}=\mathrm{H} ; \mathrm{R}_{2}=\mathrm{O}\left(\mathrm{CH}_{2}\right)_{8} \mathrm{CH}_{3}(52 \%)$
5: $\mathrm{R}_{1}=\mathrm{H} ; \mathrm{R}_{2}=\mathrm{O}\left(\mathrm{CH}_{2}\right)_{9} \mathrm{CH}_{3}(95 \%)$
6: $\mathrm{R}_{1}=\mathrm{H} ; \mathrm{R}_{2}=\mathrm{O}\left(\mathrm{CH}_{2}\right)_{11} \mathrm{CH}_{3}(96 \%)$
7: $\mathrm{R}_{1}=\mathrm{H} ; \mathrm{R}_{2}=\mathrm{O}\left(\mathrm{CH}_{2}\right)_{13} \mathrm{CH}_{3}(99 \%)$
8: $\mathrm{R}_{1}=\mathrm{F} ; \mathrm{R}_{2}=\mathrm{O}\left(\mathrm{CH}_{2}\right)_{8} \mathrm{CH}_{3}(72 \%)$
9: $\mathrm{R}_{1}=\mathrm{F} ; \mathrm{R}_{2}=\mathrm{O}\left(\mathrm{CH}_{2}\right)_{9} \mathrm{CH}_{3}(51 \%)$
10: $\mathrm{R}_{1}=\mathrm{F} ; \mathrm{R}_{2}=\mathrm{O}\left(\mathrm{CH}_{2}\right)_{13} \mathrm{CH}_{3}(74 \%)$
11: $\mathrm{R}_{1}=\mathrm{F} ; \mathrm{R}_{2}=\mathrm{CH}_{3}(55 \%)$
12: $R_{1}=F ; R_{2}=B r(42 \%)$
13: $R_{1}=F ; R_{2}=N\left(C_{3}\right)_{2}(28 \%)$
14: $\mathrm{R}_{1}=\mathrm{F} ; \mathrm{R}_{2}=\mathrm{Cl}(69 \%)$

Figure 1. General synthesis of chalcone derivatives.

important role in diverse biological activities ${ }^{16}$. These compounds are privileged scaffolds in medicinal chemistry, and various works have been reported enumerating the antiparasitic potential of pyrazoles and pyrazolines. For example, a series of pyrazole-pyrazoline substituted with benzenesulfonamide were synthesized and evaluated for their antimalarial activity in vitro and in vivo ${ }^{17}$. More recently, pyrazol(in)e derivatives of curcumin analogs have been reported as a new class of trypanosomicidal agents ${ }^{18}$. However, the reports on schistosomicidal (or anthelmintic) activities of pyrazoles and pyrazolines are scarce. In this study, a series of 17 pyrazoline derivatives were synthesized and tested in vitro on S. mansoni adult worms. Compounds were thereafter tested on mammalian cells to determine the selectivity of schistosomicidal compounds. In addition, a structure-activity relationship (SAR) study to determine the effects of the different functional groups present in these molecules was undertaken, and three pyrazoles derivatives were also tested in vitro against adult schistosomes. Finally, physicochemical properties, pharmacokinetics, drug-likeness and medicinal chemistry friendliness analysis were performed with all active compounds against S. mansoni.

\section{Results and discussion}

Chemistry. The synthesis of the pyrazoles and pyrazolines was initiated by the reaction between acetophenone and aromatic aldehyde in basic solution, generating the appropriate chalcone in $28-99 \%$ yield (Fig. 1). The latter was treated with semicarbazide hydrochloride or thiosemicarbazide, leading to the formation of the desired pyrazoline compound 15-31 (9-37\% yield) (Fig. 2). Furthermore, chalcones 11, 12 and 14 were reacted with TsNHNH2 and iodine, leading to pyrazoles $32-34$ in 6-30\% yields (Fig. 3).

Anthelmintic activity against S. mansoni. For biological screening, S. mansoni adult parasites were isolated from the mouse infection model (parasite ex vivo) and all compounds were initially screened at $50 \mu \mathrm{M}$. The gold-standard antiparasitic compound praziquantel was used as a positive control and DMSO at $0.5 \% \mathrm{v} / \mathrm{v}$ (representing the highest concentration of solvent) served as a negative control. Of the 17 pyrazolines tested, six $(16,18,19,21,22$ and 23) showed antiparasitic activity after $72 \mathrm{~h}$, and these compounds were further tested at a range of concentrations for their $\mathrm{EC}_{50}$ determination. Results of the $\mathrm{EC}_{50}$ value for each tested drug are summarized in Table 1. Among the six pyrazolines selected, compound $\mathbf{2 2}$ was the most active against adult schistosomes, with a $\mathrm{EC}_{50}$ value of $6.2 \mu \mathrm{M}$. Pyrazolines 16, 18, 19 and 21 also displayed high antischistosomal properties $\left(\mathrm{EC}_{50}<20 \mu \mathrm{M}\right)$, whereas 23 showed moderate anthelmintic activity $\left(\mathrm{EC}_{50}\right.$ of $\left.28.2 \mu \mathrm{M}\right)$. Using the log rank (Mantel-Cox) test, comparison of antiparasitic activity revealed that the order of potency was $\mathbf{2 2}$ $(P<0.001), 16$ and $18(P<0.01), 19$ and $21(P<0.01)$, and $23(P<0.001)$. For the remaining compounds tested, no $\mathrm{EC}_{50}$ values could be calculated due to lack of activity at $50 \mu \mathrm{M}$. The positive control drug praziquantel was confirmed to be highly active, with a $\mathrm{EC}_{50}$ of $0.93 \mu \mathrm{M}$. In tandem, our findings confirm that pyrazolines have a potent antiparasitic activity. Indeed, few compounds in the literature are active at low concentrations for review 
<smiles></smiles>

1: $\mathrm{R}_{1}=\mathrm{H} ; \mathrm{R}_{2}=\mathrm{O}\left(\mathrm{CH}_{2}\right)_{3} \mathrm{CH}_{3}$

4: $\mathrm{R}_{1}=\mathrm{H} ; \mathrm{R}_{2}=\mathrm{O}\left(\mathrm{CH}_{2}\right)_{8} \mathrm{CH}_{3}$

6: $\mathrm{R}_{1}=\mathrm{H} ; \mathrm{R}_{2}=\mathrm{O}\left(\mathrm{CH}_{2}\right)_{11} \mathrm{CH}_{3}$

9: $\mathrm{R}_{1}=\mathrm{F} ; \mathrm{R}_{2}=\mathrm{O}\left(\mathrm{CH}_{2}\right)_{9} \mathrm{CH}_{3}$

11: $\mathrm{R}_{1}=\mathrm{F} ; \mathrm{R}_{2}=\mathrm{CH}_{3}$

12: $R_{1}=F ; R_{2}=B r$

13: $R_{1}=F ; R_{2}=N\left(C_{3}\right)_{2}$

14: $R_{1}=F ; R_{2}=C l$<smiles>[R]c1ccc(/C=C/C(=O)c2ccc([R])cc2)cc1</smiles><smiles>CCOON(C)C(N)=S</smiles>

2: $\mathrm{R}_{1}=\mathrm{H} ; \mathrm{R}_{2}=\mathrm{O}\left(\mathrm{CH}_{2}\right)_{5} \mathrm{CH}_{3}$

3: $\mathrm{R}_{1}=\mathrm{H} ; \mathrm{R}_{2}=\mathrm{O}\left(\mathrm{CH}_{2}\right)_{7} \mathrm{CH}_{3}$

4: $\mathrm{R}_{1}=\mathrm{H} ; \mathrm{R}_{2}=\mathrm{O}\left(\mathrm{CH}_{2}\right)_{8} \mathrm{CH}_{3}$

5: $\mathrm{R}_{1}=\mathrm{H} ; \mathrm{R}_{2}=\mathrm{O}\left(\mathrm{CH}_{2}\right)_{9} \mathrm{CH}_{3}$

6: $\mathrm{R}_{1}=\mathrm{H} ; \mathrm{R}_{2}=\mathrm{O}\left(\mathrm{CH}_{2}\right)_{11} \mathrm{CH}_{3}$

7: $\mathrm{R}_{1}=\mathrm{H} ; \mathrm{R}_{2}=\mathrm{O}\left(\mathrm{CH}_{2}\right)_{13} \mathrm{CH}_{3}$

8: $\mathrm{R}_{1}=\mathrm{F} ; \mathrm{R}_{2}=\mathrm{O}\left(\mathrm{CH}_{2}\right)_{8} \mathrm{CH}_{3}$

9: $\mathrm{R}_{1}=\mathrm{F} ; \mathrm{R}_{2}=\mathrm{O}\left(\mathrm{CH}_{2}\right)_{9} \mathrm{CH}_{3}$

10: $\mathrm{R}_{1}=\mathrm{F} ; \mathrm{R}_{2}=\mathrm{O}\left(\mathrm{CH}_{2}\right)_{13} \mathrm{CH}_{3}$<smiles>[R]c1ccc(C2=NN(C(N)=O)C(C)(C)[C@H]2C)cc1</smiles>

15: $\mathrm{R}_{1}=\mathrm{H} ; \mathrm{R}_{2}=\mathrm{O}\left(\mathrm{CH}_{2}\right)_{3} \mathrm{CH}_{3}(30 \%)$

16: $\mathrm{R}_{1}=\mathrm{H} ; \mathrm{R}_{2}=\mathrm{O}\left(\mathrm{CH}_{2}\right)_{8} \mathrm{CH}_{3}(25 \%)$

17: $\mathrm{R}_{1}=\mathrm{H} ; \mathrm{R}_{2}=\mathrm{O}\left(\mathrm{CH}_{2}\right)_{11} \mathrm{CH}_{3}(22 \%)$

18: $\mathrm{R}_{1}=\mathrm{F} ; \mathrm{R}_{2}=\mathrm{O}\left(\mathrm{CH}_{2}\right)_{9} \mathrm{CH}_{3}(22 \%)$

19: $R_{1}=F ; R_{2}=\mathrm{CH}_{3}(13 \%)$

20: $R_{1}=F ; R_{2}=B r(9 \%)$

21: $R_{1}=F ; R_{2}=N\left(C_{3}\right)_{2}(17 \%)$

22: $R_{1}=F ; R_{2}=C l(15 \%)$

Figure 2. General synthesis of pyrazolines derivatives.<smiles>[R]c1ccc(/C=C/C(=O)c2ccc([R])cc2)cc1</smiles>

$\mathrm{TsNHNH}_{2}$ (1.2 eq.)<smiles></smiles>

11: $\mathrm{R}_{1}=\mathrm{F} ; \mathrm{R}_{2}=\mathrm{CH}_{3}$

12: $R_{1}=F ; R_{2}=B r$

14: $\mathrm{R}_{1}=\mathrm{F} ; \mathrm{R}_{2}=\mathrm{Cl}$<smiles>[R]c1ccc(-c2n[nH]c(-c3ccc([R])cc3)c2C)cc1</smiles>

32: $\mathrm{R}_{1}=\mathrm{F} ; \mathrm{R}_{2}=\mathrm{CH}_{3}(16 \%)$

33: $\mathrm{R}_{1}=\mathrm{F} ; \mathrm{R}_{2}=\mathrm{Br}(30 \%)$

34: $\mathrm{R}_{1}=\mathrm{F} ; \mathrm{R}_{2}=\mathrm{Cl}(6 \%)$

Figure 3. General synthesis of pyrazoles derivatives.

see $^{11,19}$. According to criteria established by the World Health Organization (WHO) for antiparasitic hits, leads, and drug candidates, at the start of a screening campaign a compound should inhibit mobility of helminths in vitro at $10 \mu \mathrm{g} / \mathrm{mL}^{20}$, commonly ranging from 30 to $40 \mu \mathrm{M}$. Thus, the anthelminthic activity of pyrazolines surpasses criteria established by the WHO.

Assays regarding the survival times of $S$. mansoni were also performed with pyrazolines 16, 18, 19, 21, 22 and 23 to understand the kinetics and mode of action of these compounds. The viability of the schistosomes over a period of $72 \mathrm{~h}$ in vitro is demonstrated in Fig. 4. Control worms remained viable over the entire observation period. Pyrazolines induced mortality in schistosomes in a time- and concentration-dependent manner. In more details, pyrazolines 16, 18, 19 and 22 were able to kill all parasites within $24 \mathrm{~h}$ of contact at a concentration of $50 \mu \mathrm{M}$. Under the same timetable, the death of all worms exposed to compounds $\mathbf{1 6}$ and $\mathbf{2 2}$ at a concentration of $25 \mu \mathrm{M}$ was observed. A slightly slower onset of action was seen when schistosomes were incubated with 


\begin{tabular}{|l|l|l|l|l|l|}
\hline \multirow{2}{*}{ Compounds } & S. mansoni & \multicolumn{2}{l|}{ Monkey cells } & \multicolumn{2}{l|}{ Human cells } \\
\cline { 2 - 6 } & $\mathbf{E C}_{50}(\boldsymbol{\mu M})$ & $\mathrm{CC}_{50}(\boldsymbol{\mu M})$ & SI & CC $_{50}(\boldsymbol{\mu M})$ & SI \\
\hline $\mathbf{1 5}$ & $>50$ & N.D & N.D & N.D & N.D \\
\hline $\mathbf{1 6}$ & $13.8[9.6-17.4]^{*}$ & $154.8[122.5-184.2]$ & 11.2 & $>200$ & $>14.5$ \\
\hline $\mathbf{1 7}$ & $>50$ & N.D & N.D & N.D & N.D \\
\hline $\mathbf{1 8}$ & $14.6[9.4-19.1]$ & $158.9[118.9-194.3]$ & 10.9 & $>200$ & $>13.7$ \\
\hline $\mathbf{1 9}$ & $17.4[11.2-21.6]$ & $168.6[120.6-200]$ & 9.7 & $>200$ & $>11.5$ \\
\hline $\mathbf{2 0}$ & $>50$ & N.D & N.D & N.D & N.D \\
\hline $\mathbf{2 1}$ & $19.8[12.4-23.9]$ & $>200$ & $>10.1$ & $>200$ & $>10.1$ \\
\hline $\mathbf{2 2}$ & $6.2[4.1-10.3]$ & $134.3[101.2-160.6]$ & 21.6 & $>200$ & $>32.2$ \\
\hline $\mathbf{2 3}$ & $28.2[21.7-35.9]$ & $>200$ & $>7.1$ & $>200$ & $>7.1$ \\
\hline $\mathbf{2 4}$ & $>50$ & N.D & N.D & N.D & N.D \\
\hline $\mathbf{2 5}$ & $>50$ & N.D & N.D & N.D & N.D \\
\hline $\mathbf{2 6}$ & $>50$ & N.D & N.D & N.D & N.D \\
\hline $\mathbf{2 7}$ & $>50$ & N.D & N.D & N.D & N.D \\
\hline $\mathbf{2 8}$ & $>50$ & N.D & N.D & N.D & N.D \\
\hline $\mathbf{2 9}$ & $>50$ & N.D & N.D & N.D & N.D \\
\hline $\mathbf{3 0}$ & $>50$ & N.D & N.D & N.D & N.D \\
\hline $\mathbf{3 1}$ & $>50$ & N.D & N.D & N.D & N.D \\
\hline $\mathbf{3 2}$ & $>50$ & N.D & N.D & N.D & N.D \\
\hline $\mathbf{3 3}$ & $>50$ & N.D & N.D & N.D & N.D \\
\hline $\mathbf{3 4}$ & $>50$ & N.D & N.D & N.D & N.D \\
\hline $\mathbf{P Z Q ~}$ & $0.93[0.81-1.2]$ & $>200$ & $>200$ & $>200$ & $>200$ \\
\hline & & & & \\
\hline & & & & & \\
\hline
\end{tabular}

Table 1. In vitro activity of pyrazolines against $S$. mansoni adult worm and and cytotoxicity. $E C_{50}$ effetive concentration $50 \%$ against adult schistosomes, $C C_{50}$ cytotoxic concentration $50 \%$ against monkey (Vero) or human (SH-SY5Y) cells, SI selectivity index, ND not determined. ${ }^{\star} 95 \%$ Confidence Interval.

pyrazolines 21 and 23. For example, all parasites died after $48 \mathrm{~h}$ of exposure to compound 21 at $50 \mu \mathrm{M}$, whereas compound 23 at $50 \mu \mathrm{M}$ induced $100 \%$ mortality after $72 \mathrm{~h}$. The precise mechanism of action, however, remains to be determined. The known antischistosomal drug praziquantel shows a fast-killing profile against adult $S$. mansoni.

Based on antischistosomal properties of pyrazolines 16, 18, 19, 21, 22 and 23, the ability of these six compounds to affect fecundity (egg production) was subsequently measured. Interestingly, a complete lack of oviposition was observed when adult worm pairs were exposed to pyrazolines at 25 and $50 \mu \mathrm{M}$. To further investigate this effect on schistosome fecundity, parasites were tested using sublethal concentrations $(3.5 \mu \mathrm{M}$ for compound $\mathbf{2 2}, 6.25 \mu \mathrm{M}$ for compound 16, and $12.5 \mu \mathrm{M}$ for compounds $\mathbf{1 8}, \mathbf{1 9}, \mathbf{2 1}$, and 23). Compared to control parasites, pyrazolines 16, 19, and 23 demonstrated a negative effect on schistosome fecundity, with a reduction of 30-70\% in the number of eggs (Fig. 5). Due to the high relevance of eggs for both disease transmission and pathology, the results revealed the potential of pyrazolines $16,18,19,21,22$ and 23 , as antischistosomal agents.

Cytotoxicity evaluation and selectivity index. The selectivity index (SI) of a compound is a widely accepted parameter used to express a drug's in vitro efficacy. Therefore, the cytotoxic effect of these six pyrazolines $(16,18,19,21,22$ and 23) was evaluated using a monkey cell line (Vero) and a human cell line (SH-SY5Y). Cells were incubated with each compound at a range of concentrations for determination of cytotoxic concentrations $50 \%\left(C_{50}\right)$. The average $C_{50}$ of each pyrazoline is summarized in Table 1 . All pyrazolines active against $S$. mansoni showed a low potential of cytotoxicity, with $\mathrm{CC}_{50}$ values $>130 \mu \mathrm{M}$ and $>200 \mu \mathrm{M}$ for Vero and SH-SY5Y, respectively. With the $\mathrm{EC}_{50}$ data collected for schistosomes as well as the $\mathrm{CC}_{50}$ for animal and human cells, the selectivity indices (SI) were determined for each of the pyrazolines tested (Table 1). Pyrazoline 22 had the lowest $\mathrm{CC}_{50}$ values $\left(134.3 \mu \mathrm{M}\right.$ for Vero and $>200 \mu \mathrm{M}$ for SH-SY5Y); however, it also had the lowest $\mathrm{EC}_{50}$ values of all the pyrazolines tested $(6.2 \mu \mathrm{M})$, which resulted in the higher SI scores (21.6 and 32.2 for Vero and SH-SY5Y, respectively). Compound 16, with an $\mathrm{EC}_{50}=13.8 \mu \mathrm{M}$ and $\mathrm{CCC}_{50}=154.8 \mu \mathrm{M}$ (Vero) and a $\mathrm{CC}_{50}=200 \mu \mathrm{M}(\mathrm{SH}-$ $\mathrm{SY} 5 \mathrm{Y}$ ), resulted in a $\mathrm{SI}=11.2$ and a $\mathrm{SI}=14.5$, for animal and human cell lines, respectively. Similar data for $\mathrm{EC}_{50}$ and $\mathrm{CC}_{50}$ were recorded for compounds 18 and 19, resulting in SI values of 10.9 and 9.7 for Vero cells and 13.7 and 11.5 for SH-SY5Y, respectively. Compound 21, with an $\mathrm{EC}_{50}=19.8 \mu \mathrm{M}$ and cytotoxicity greater than $200 \mu \mathrm{M}$, resulted in SI $>10$ for both animal and human cell lines. A SI value $\geq 10$ is in accordance with the criteria defined by the WHO for antiparasitic hits, leads, and drug candidates ${ }^{20}$. In this study, most pyrazolines tested had SI value $\geq 10$, demonstrating the highly selective anthelmintic effect of pyrazolines. Comparatively, the SI values achieved with pyrazolines exceeded those obtained for other relevant heterocyclic compounds with antischistosomal properties ${ }^{21,22}$. Although the SI values recorded for pyrazolines were more than 10 times below those for the reference drug praziquantel, a SI value $\geq 10$ fulfills and exceeds the criteria established by the WHO for potential compounds as anthelmintic agents ${ }^{20}$. 

- Control
$25 \mu \mathrm{M}$
$-6.25 \mu \mathrm{M}$
-. $50 \mu \mathrm{M}$
$12.5 \mu \mathrm{M}$
- PZQ

(16)
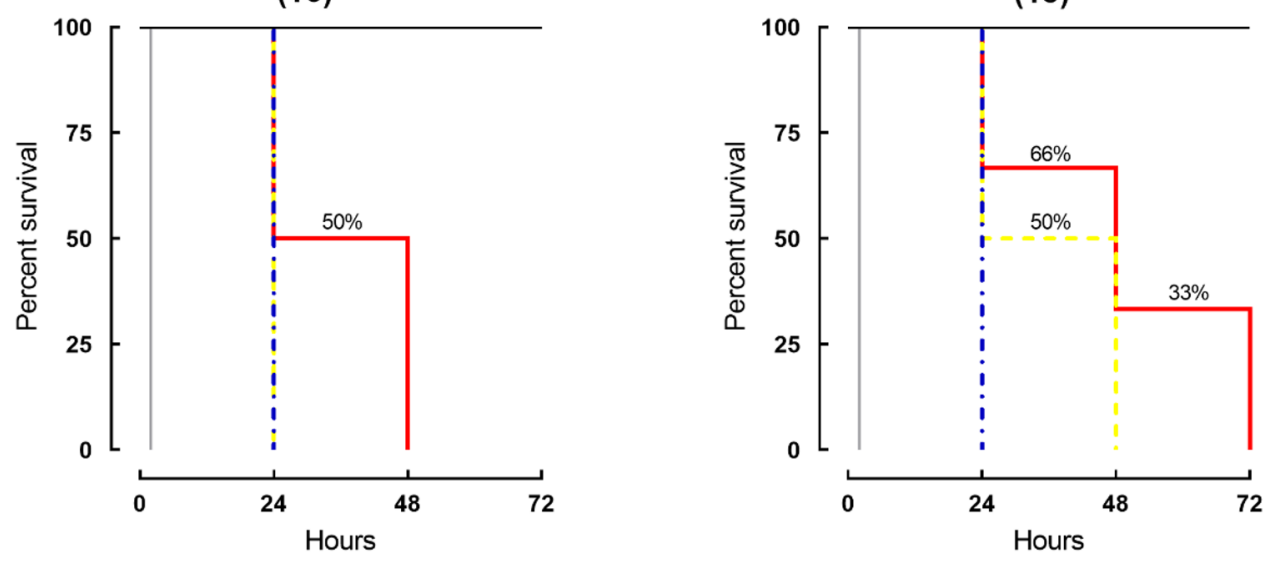

(19)

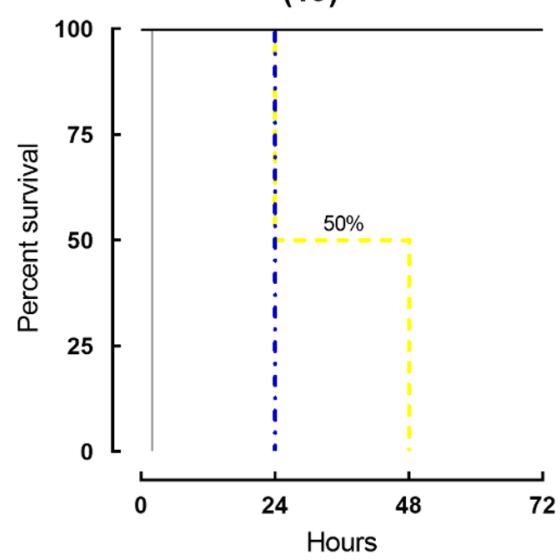

(21)

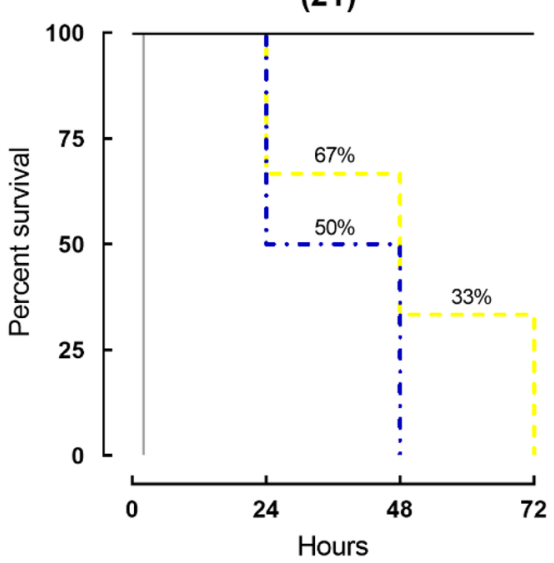

(22)
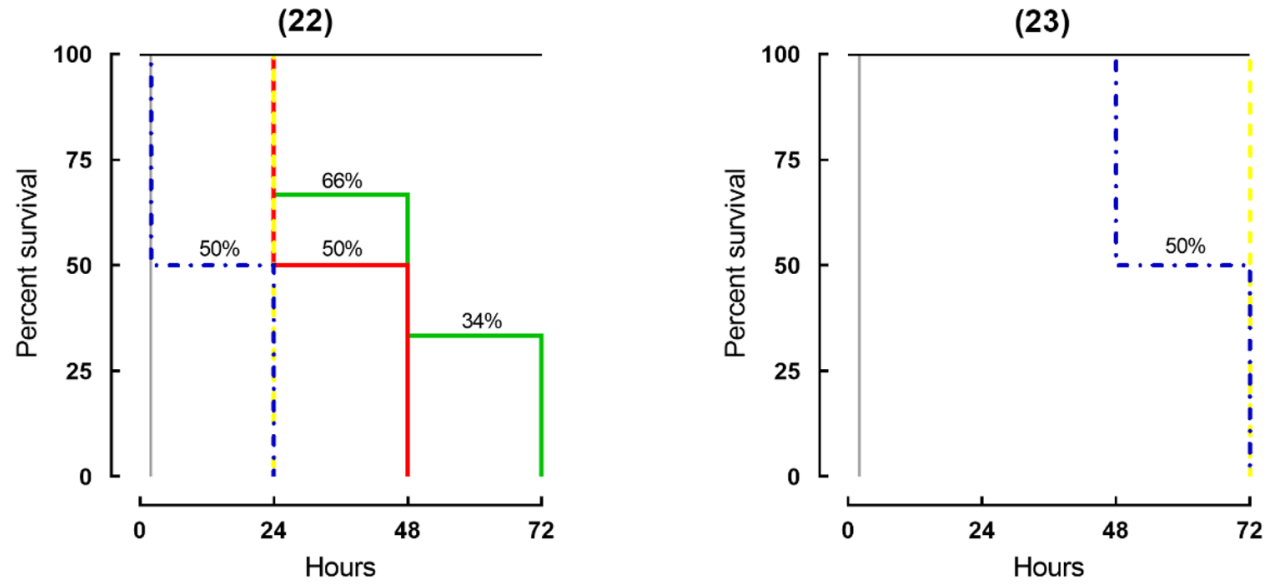

Figure 4. Viability of ex vivo adult $S$. mansoni worms following exposure to pyrazolines 16, 18, 19, 21, 22 and 23. Parasites were obtained from mice by perfusion 49 days after infection. Parasites were monitored for up to $72 \mathrm{~h}$, and results are expressed as the percent mortality recorded by Kaplan-Meier survival curves. Mean values of viability were derived from a minimum of three experiments $(n=3)$. Control: drug-free medium. PZQ: praziquantel at $2 \mu \mathrm{M}$. 


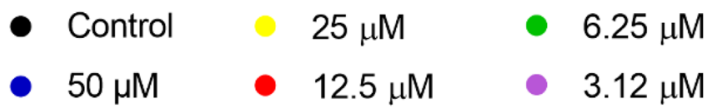

(16)

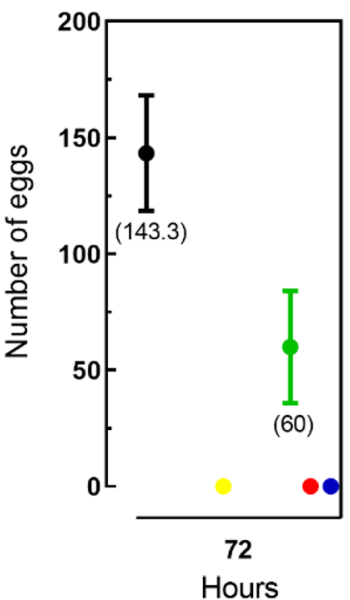

(21)

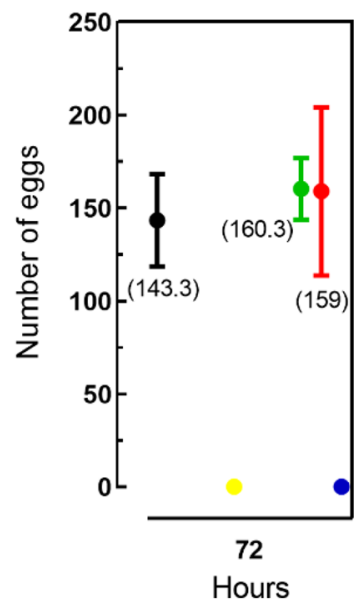

(18)

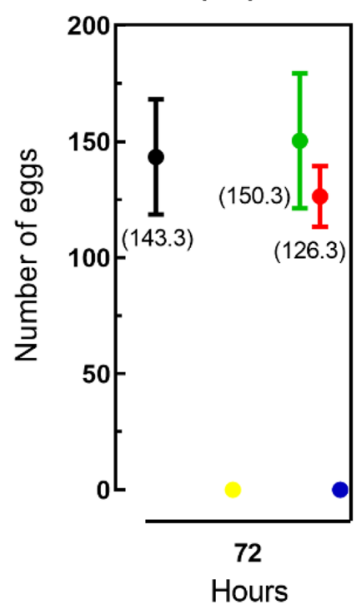

(22)

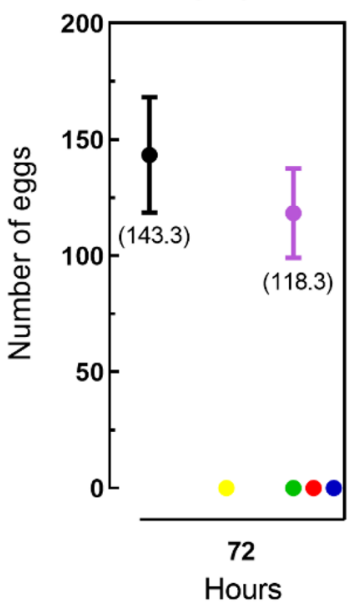

(19)

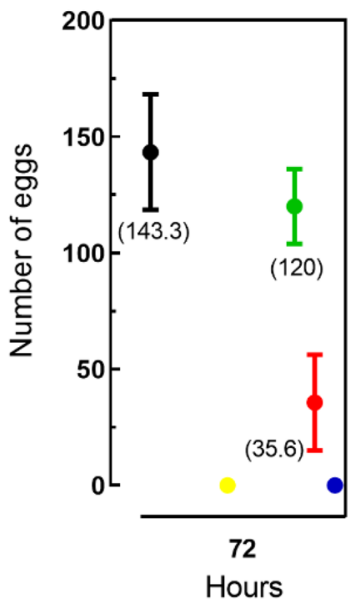

(23)

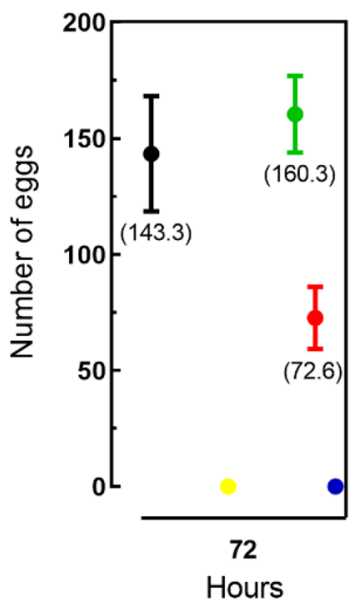

Figure 5. Number of eggs released by paired adult schistosomes exposed to pyrazolines 16, 18, 19, 21, 22 and 23. Control: drug-free medium. Data are presented as the mean \pm SD from three experiments $(n=3)$.

SAR plan and analysis. The According to these biological results, it is possible to establish a structural relationship among the compounds tested. Of the 17 pyrazolines tested, 13 have $O$-alkyl chains in their structures (15-18, 23-31), but only three of these compounds (16, 18 and 23), with carbon chains of different sizes $(9,10$ and $6 \mathrm{C}$, respectively), showed some biological potential. These results may indicate that this change is not an essential factor for the biological activity of this series of compounds.

In agreement with the previous inference, four (19-22) compounds without $O$-alkyl chains in their structure were tested, and three of them (19,21 and 22) showed good schistosomicidal activity, which indicates that the presence of less bulky groups as substituents in the aromatic rings favors the biological activity of the compounds ${ }^{23}$.

Among the eight compounds derived from the semicarbazide tested (15-22), five (16, 18, 19, 21 and 22) had biological potential with $\mathrm{EC}_{50}$ between 6.2 and $19.8 \mu \mathrm{M}$ and selectivity ranging from 9.7 to 21.6 and four $(\mathbf{1 8}, \mathbf{1 9}$, 21 and 22) of the compounds had the fluorine substituent in the para position of the aromatic ring from acetophenone, which suggests that halogen plays an important role in the antiparasitic activity of such compounds ${ }^{23}$.

Regarding compounds derived from thiosemicarbazide, among the nine compounds tested (23-31), only compound 23 showed antischistosomal activity with $\mathrm{EC}_{50}=28.2 \mu \mathrm{M}$ and IS $>7$.

Of the six compounds $(\mathbf{1 6}, \mathbf{1 8}, \mathbf{1 9}, \mathbf{2 1}, 22$ and $\mathbf{2 3})$ that showed activity against $S$. mansoni, five $(\mathbf{1 6}, \mathbf{1 8}, \mathbf{1 9}$, 21 and 22) are derived from semicarbazide, while only compound 23 is derived from thiosemicarbazide. This may indicate that the presence of the semicarbazide portion is of relative importance for the antischistosomal activity of pyrazolines. 


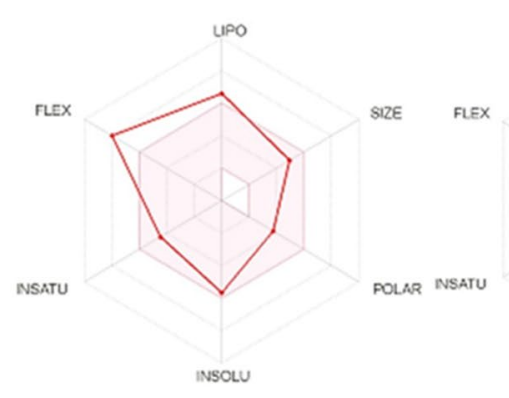

(21)

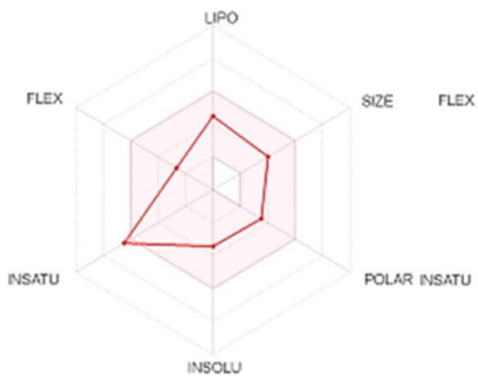

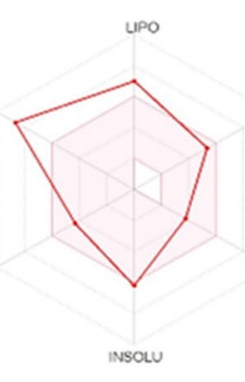

(22)

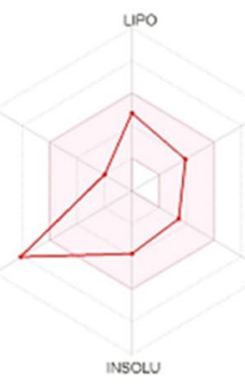

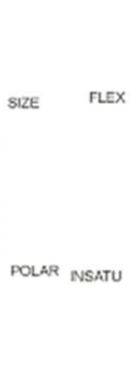

SIZE

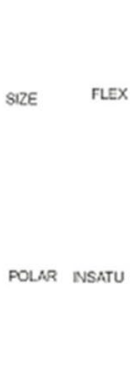

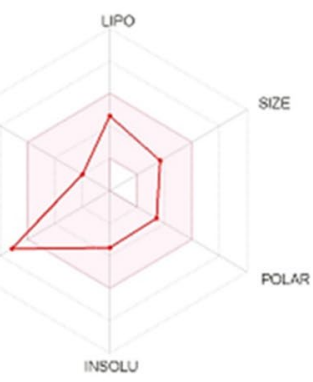

(23)

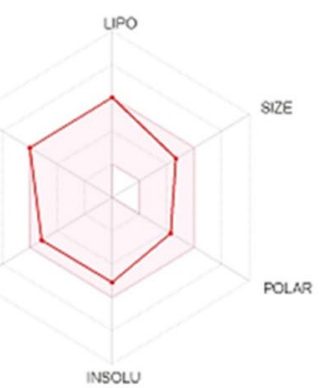

Figure 6. Bioavailability radar plots of pyrazolines 16, 18, 19, 21, 22 and 23 . The pink area represent the optimal range for each property, and the red line represents the values of the six calculated properties. lipophilicity: XLOGP3 between - 0.7 and + 5.0, size: molecular weight between 150 and $500 \mathrm{~g} / \mathrm{mol}$, polarity: topological polar surface area (TPSA) between 20 and $130 \AA^{2}$, solubility: log S not higher than 6 , saturation: fraction of carbons in the sp3 hybridization not less than 0.25 , and flexibility: no more than 9 rotatable bonds. Plots were performed using the SwissADME tool.

In order to locate the pharmacophoric group of the compounds tested, the antischistosomal properties of some pyrazoles, aromatic nitrogenous heterocycles of the same class as pyrazolines, were also evaluated. Regarding this scenario, the influence of the pyrazoline heterocycle and the N-substitution of the compounds on their biological activity was evaluated. Thus, three pyrazoles (32-34) were tested under the same conditions. None of the three pyrazoles showed biological activity against $S$. mansoni adult worms. This may indicate that the presence of the non-aromatic heterocycle and N-substitution are fundamental to the antischistosomal properties of the compounds, as observed while comparing pyrazoles 32 and 34, which do not have biological potential $\left(\mathrm{EC}_{50}>50 \mu \mathrm{M}\right)$, and pyrazolines 19 and 22 , which have good activity with $\mathrm{EC}_{50}$ of 17.4 and $6.2 \mu \mathrm{M}$ and selectivity index of 9.7 and 21.6, respectively.

Physicochemical properties and drug-likeness parameters. The druggability of pyrazolines 16, $18,19,21,22$ and 23 was performed in silico to investigate the physicochemical properties, pharmacokinetic parameters, and drug-likeness (Fig. 6, Tables 2 and 3). Initially, the obtained results on the bioavailability radar (Fig. 6), which considers six physicochemical properties such as lipophilicity, size, polarity, solubility, flexibility and saturation to detect drug-likeness, indicate good adherence of pyrazolines to all evaluated parameters, except flexibility (compounds $\mathbf{1 6}$ and 18) and unsaturation (compounds 19 and 22).

Our in silico analysis also suggested adequate "drug-like" parameters associated with gastrointestinal absorption (GI) and oral bioavailability, according to ClogP and TPSA values. With the exception of compound 16, pharmacokinetic analysis also indicated no interactions with P-glycoprotein (P-gp). Pyrazolines 16, 19, 21, and 22 were predicted to be permeant to the blood brain barrier (BBB), a possibly interesting feature in cases of cerebral schistosomiasis. Moreover, the prediction for these compounds did not indicate inhibitory activity for the CYP1A2 isoforms, emphasizing the low potential for drug interactions. Computational analysis also suggested that pyrazolines 16, 18, 19, 22 and 23 are not Pan-Assay Interference Sub-structures (PAINS, also kwon as frequent hitters or promiscuous compounds $)^{28}$. Thus, there is a reduced probability that the antischistosomal properties of the tested pyrazolines could be considered artifacts caused by promiscuous reactivity. In addition, with the exception of compound 23, which had a thiocarbonyl group, no structural alert identified from Brenk filter for drug discovery for neglected diseases ${ }^{29}$ was identified for pyrazolines. Collectively, these findings suggested that pyrazolines exhibited desirable characteristic of a drug candidates.

In the pharmaceutical industry, there has been a growing interest in the computational prediction of synthetic difficulty ${ }^{30}$. All six active pyrazolines are synthetically viable and accessible to experimental testing, as demonstrated by computational prediction of a synthetically accessibility score. It is important to report that all compounds were easily synthetized in sufficient quantities for in vitro bioassays. 


\begin{tabular}{|l|l|l|l|l|l|l|}
\hline \multirow{2}{*}{ Parameters } & \multicolumn{7}{|l}{ Pyrazolines } & $\mathbf{1 6}$ & $\mathbf{1 8}$ & $\mathbf{1 9}$ & $\mathbf{2 1}$ & $\mathbf{2 2}$ & $\mathbf{2 3}$ \\
\cline { 2 - 8 } & 4.12 & 4.7 & 3.3 & 2.97 & 3.57 & 3.51 \\
\hline ClogP & 67.92 & 67.92 & 58.69 & 61.93 & 58.69 & 82.94 \\
\hline TPSA $\left(\AA^{2}\right)$ & High & High & High & High & High & High \\
\hline GI absorption & Yes & No & Yes & Yes & Yes & No \\
\hline BBB permeation & No & No & No & No & No & No \\
\hline CYP1A2 inhibitor & Yes & No & No & No & No & No \\
\hline P-gp substrate & No & No & No & Yes & No & No \\
\hline PAINS & No & No & No & No & No & Yes \\
\hline Brenk alert & 4.04 & 4.18 & 3.29 & 3.39 & 3.21 & 3.90 \\
\hline SA & & & & & & \\
\hline
\end{tabular}

Table 2. Physicochemical and pharmacokinetic prediction for pyrazolines 16, 18, 19, 21, 22 and 23. $C \log P$ logarithm of n-octanol/water, TPSA topological polar surface area, GI gastrointestinal absorption, $B B B$ blood-brain barrier penetration, CYP1A2 cytochrome P450 family 1 subfamily A member 2, involved in the metabolism of xenobiotics, PAINS pan-assay interference substructures, SA Synthetic accessibility, scored from 1 (very easy) to 10 (very difficult). In silico prediction was performed using SwissADME platform.

\begin{tabular}{|c|c|c|c|c|c|c|}
\hline \multirow{2}{*}{$\begin{array}{l}\text { Pharmaceutical } \\
\text { companies }\end{array}$} & \multicolumn{6}{|l|}{ Pyrazolines } \\
\hline & 16 & 18 & 19 & 21 & 22 & 23 \\
\hline Pfizer (Lipinski) ${ }^{\mathrm{a}}$ & Yes, 0 violation & Yes, 0 violation & Yes, 0 violation & Yes, 0 violation & Yes, 0 violation & Yes, 0 violation \\
\hline GSK (Veber) ${ }^{\mathrm{b}}$ & $\begin{array}{l}\text { No, } 1 \text { violation: } \\
\text { Rotors }>10\end{array}$ & $\begin{array}{l}\text { No, } 1 \text { violation: } \\
\text { Rotors }>10\end{array}$ & Yes, 0 violation & Yes, 0 violation & Yes, 0 violation & Yes, 0 violation \\
\hline Pharmacia $(\text { Egan })^{c}$ & Yes & $\begin{array}{l}\text { No, } 1 \text { violation: } \\
\text { WLOGP > 5.88 }\end{array}$ & Yes, 0 violation & Yes, 0 violation & Yes, 0 violation & Yes, 0 violation \\
\hline Bayern (Muegge) ${ }^{\mathrm{d}}$ & $\begin{array}{l}\text { No, } 1 \text { violation: } \\
\text { XLOGP3 > 5 }\end{array}$ & $\begin{array}{l}\text { No, } 1 \text { violation: } \\
\text { XLOGP3 > } 5\end{array}$ & Yes, 0 violation & Yes, 0 violation & Yes, 0 violation & Yes, 0 violation \\
\hline Amgen (Ghose) ${ }^{\mathrm{e}}$ & $\begin{array}{l}\text { No, } 1 \text { violation: } \\
\text { MR > } 130\end{array}$ & $\begin{array}{l}\text { No, } 2 \text { violations: } \\
\text { WLOGP > 5.6, } \\
M R>130\end{array}$ & Yes, 0 violation & Yes, 0 violation & Yes, 0 violation & Yes, 0 violation \\
\hline
\end{tabular}

Table 3. Drug-likeness and adherence to major pharmaceutical companies' filters. $M W$ molecular weight, $M R$ molecular refractivity, $\log P \operatorname{logarithm}$ of n-octanol/water, XLOGP3 atomistic method including corrective factors and knowledge-based library, WLOGP atomistic method based on the fragmental system, $H B A$ hydrogen bond acceptor, HBD hydrogen bond donor, TPSA topological polar surface area. In silico prediction was performed using SwissADME platform. ${ }^{a}$ Lipinski filter ${ }^{24}$ : MW $\leq 500 ; \operatorname{LogP} \leq 5 ; \mathrm{HBA} \leq 10 ; \mathrm{HBD} \leq 5$. ${ }^{b}$ Veber filter ${ }^{25}$ : Rotatable bonds $\leq 10$; TPSA $\leq 140 .{ }^{\text {c }}$ Egan filter ${ }^{26}$ : WLOGP $\leq 5.88$; TPSA $\leq 131.6 .{ }^{\mathrm{d}}$ Muegge filter $^{27}$ :

$200 \leq \mathrm{MW} \leq 600 ;-2 \leq \mathrm{XLOGP} \leq 5$; TPSA $\leq 150$; rings $\leq 7$; carbon $>4$; heteroatoms $>1$; rotatable bonds $\leq 15$; $\mathrm{HBA} \leq 10 ; \mathrm{HBD} \leq 5$. ${ }^{\mathrm{e}}$ Ghose filter ${ }^{44}: 160 \leq \mathrm{MW} \leq 480 ;-0.4 \leq \mathrm{WLOGP} \leq 5.6 ;-0.4 \leq \mathrm{MR} \leq 130 ; 20 \leq$ atoms $\leq 70$.

The adherence to leading pharmaceutical companies such as Pfizer (Lipinski) ${ }^{31}$, GSK (Veber) ${ }^{32}$, Pharmacia $(\text { Egan })^{33}$, Bayer (Muegge) $)^{34}$ and Amgen (Ghose) $)^{35}$ by computational filters was also performed to evaluate the drug-likeness of pyrazolines (Table 3). Interestingly, none of the tested pyrazolines violated Lipinski's rule, the most widely used filter to estimate solubility and permeability in drug discovery and development settings. Considering the filters developed by major pharmaceutical companies, pyrazolines 19, 21, 22 and 23 followed five drug-likeness rules, supporting the use of these compounds as suitable drug candidates.

In conclusion, a series of 17 pyrazolines (15-31) and three pyrazoles (32-34) were synthesized and six (16, $18,19,21,22$ and 23) were found to have an antiparasitic activity in the micromolar range when tested against $S$. mansoni ex vivo. These compounds have low cytotoxicity for animal and human cell lines, with an excellent selectivity profile. In addition, all active pyrazolines demonstrated a negative effect on schistosome fecundity, with a marked reduction in the number of eggs. Structure-activity relationship analysis showed that the presence of the non-aromatic heterocycle and $\mathrm{N}$-substitution are fundamental to the antischistosomal properties. As recommended for drug screening against helminths, a promising agent should be active against adult worms at $10 \mu \mathrm{g} / \mathrm{mL}$ (typically ranging from 30 to $40 \mu \mathrm{M}$ ) and display a high SI ( $\geq 10$ ). In this study, all these requirements were fulfilled, especially by $\mathbf{1 6}, \mathbf{1 8}, \mathbf{2 1}$, and $\mathbf{2 2}$. Finally, physicochemical properties and drug-likeness parameters of pyrazolines demonstrated excellent adherence to all analyzed properties as well as in adherence to major pharmaceutical companies. Among the six pyrazolines tested, compound 22 was highly active against adult schistosomes $\left(\mathrm{EC}_{50}\right.$ value of $\left.6.2 \mu \mathrm{M}\right)$ and it displayed desirable characteristic of a good drug candidate. Overall, this study demonstrates that pyrazoline derivatives are promising scaffolds in the discovery of new antischistosomal agents and opens new avenues in the search for drug candidates against schistosomiasis. 


\section{Methods}

Chemistry. Chalcones, pyrazolines and pyrazoles were prepared according to the method previously described ${ }^{36,37}$. The chemical structures of all compounds are presented in Figs. 1, 2 and 3.

All the reagents and solvents were purchased as reagent grade and used without any purification. Thin layer chromatography (TLC) was performed on glass plates (silica gel F254; Merck), using ultraviolet light (264 nm) and/or iodine vapor as revelator. Melting points were determined on a MQAPF-Microquimica apparatus. IR spectra were acquired using a Bruker Alpha-E ATR (Attenuated Total Reflection) spectrometer. NMR data were recorded on a Bruker 500 Advance Spectrometer. NMR experiments were conducted in deuterochloroform $(\mathrm{CDCl} 3)$ and deuterodimethylsulfoxide (DMSO-d6). The chemical shifts values $(\delta)$ were reported in parts per million (ppm) with tetramethylsilane (TMS) as internal reference. The following abbreviations are used to explain the multiplicities: $\mathrm{s}=$ singlet; $\mathrm{d}=$ doublet; $\mathrm{dd}=$ double doublet; $\mathrm{t}=$ triplet and brs = broad singlet and coupling constants $(\mathrm{J})$ are reported in Hertz $(\mathrm{Hz})$.

All the structural data collected are presented in Supplementary Information.

Preparation of chalcones derivatives (1-14). Into an ethanolic solution of $\mathrm{NaOH} 4 \mathrm{M}(1.6 \mathrm{~g}$ of $\mathrm{NaOH}$ in $10 \mathrm{~mL}$ of ethanol) was added 1 equivalent of the respective acetophenone $(4 \mathrm{mmol})$ and 1 equivalent of the aromatic aldehyde $(4 \mathrm{mmol})$. The reaction was left under magnetic stirring at room temperature until conversion was complete, as evidenced by TLC (eluent: 100\% DCM, revelator: ultraviolet light and I vapor). The crude was neutralized with $4 \mathrm{M} \mathrm{HCl}$ and kept in refrigerator overnight. Once precipitated, they were vacuum filtered and washed with ethanol. The crude was recrystallized from ethanol or methanol in order to obtain the pure compounds. The assignment of the structures is fully supported by their characteristic shift values.

Preparation of pyrazolines derivatives (15-31). The pyrazolines were synthesized according to a previously published procedure ${ }^{22}$. A solution of the appropriate chalcone $(1 \mathrm{eq}$.) in absolute ethanol $(20 \mathrm{~mL})$ and hydrazide (semicarbazide hydrochloride or thiosemicarbazide, 2 eq.) was treated with $\mathrm{NaOH}$ (2.5 eq.) in ethanol $(10 \mathrm{~mL})$. The reaction mixture was heated under reflux until the complete disappearance of the starting materials as evidenced by TLC (revelator: ultraviolet light, iodine vapors and/or $20 \% \mathrm{H}_{2} \mathrm{SO}_{4}$ solution). The precipitates were filtered, washed with a cold mixture of ethanol/water, dried and recrystallized from suitable solvent to give pure compound. The 1H NMR spectra of compounds 15-31 are shown in Supplementary Information.

5-(4-butoxyphenyl)-4,5-dihydro-3-phenylpyrazole-1-carboxamide (15). Yield: 30\%; 1H NMR (300 MHz, DMSO-d6) $\delta(\mathrm{ppm}): 0.90\left(\mathrm{t}, 3 \mathrm{H}, \mathrm{J}=6.6 \mathrm{~Hz}, \mathrm{CH}_{3}\right) ; 1.34-1.70\left(\mathrm{~m}, 4 \mathrm{H},-\mathrm{CH}_{2}-\right) ; 3.03(\mathrm{dd}, 1 \mathrm{H}, \mathrm{Ja}, \mathrm{x}=5.1 \mathrm{~Hz}$, $\mathrm{Ja}, \mathrm{b}=17.7 \mathrm{~Hz}, \mathrm{Ha}) ; 3.76$ (dd, 3H, Jb,x=12.0 Hz, Jb, a = 17.7 Hz, Hb); 3.91 (t, 2H, J =6.6 Hz, -OCH2-); 5.35 (dd, $1 \mathrm{H}, \mathrm{Jx}, \mathrm{a}=5.1 \mathrm{~Hz}, \mathrm{Jx}, \mathrm{b}=12.0 \mathrm{~Hz}, \mathrm{Hx}) ; 6.49(\mathrm{sl}, 2 \mathrm{H}, \mathrm{NH}) ; 6.84-7.80(\mathrm{~m}, 9 \mathrm{H})$.

4,5-dihydro-5-(4-(nonyloxy)phenyl)-3-phenylpyrazole-1-carboxamide (16). Yield: $25 \%$; mp: $91.8-94.2{ }^{\circ} \mathrm{C} ; 1 \mathrm{H}$ NMR (300 MHz, CDCl3) $\delta(\mathrm{ppm}): 0.86(\mathrm{sl}, 3 \mathrm{H}, \mathrm{CH} 3) ; 1.25-1.77$ (m, $14 \mathrm{H},-\mathrm{CH} 2-)$; 3.14 (dd, $1 \mathrm{H}, \mathrm{Ja}, \mathrm{x}=4.8 \mathrm{~Hz}$, $\mathrm{Ja}, \mathrm{b}=17.7 \mathrm{~Hz}, \mathrm{Ha}) ; 3.73(\mathrm{dd}, 1 \mathrm{H}, \mathrm{Jb}, \mathrm{x}=12.0 \mathrm{~Hz}, \mathrm{Jb}, \mathrm{a}=17.7 \mathrm{~Hz}, \mathrm{Hb}) ; 3.88$ (t, 2H, J=6.6 Hz, -OCH2-5.46 (dd, $1 \mathrm{H}, \mathrm{Jx}, \mathrm{a}=4.8 \mathrm{~Hz}, \mathrm{Jx}, \mathrm{b}=12.0 \mathrm{~Hz}, \mathrm{Hx}) ; 6.84-7.71(\mathrm{~m}, 9 \mathrm{H}) .13 \mathrm{C} \mathrm{NMR}(75 \mathrm{MHz}, \mathrm{CDCl} 3) \delta(\mathrm{ppm}): 14.2-32.0$ (Caliphatic); 43.1; 59.8; 68.2 (-OCH2-); 115.0-134.6 (Caromatic); $152.1(\mathrm{C}=\mathrm{N}) ; 155.4(\mathrm{C}=\mathrm{O}) ; 158.8$.

5-(4-(dodecyloxy)phenyl)-4,5-dihydro-3-phenylpyrazole-1-carboxamide (17). Yield: $22 \%$; mp: $94.8-97.9^{\circ} \mathrm{C}$; $1 \mathrm{H}$ NMR (300 MHz, DMSO-d6) $\delta$ (ppm): 0.84 (t, 3H, J =6.6 Hz, CH3); 1.22-1.70 (m, $20 \mathrm{H},-\mathrm{CH} 2-)$; 3.02 (dd, $1 \mathrm{H}, \mathrm{Ja}, \mathrm{x}=5.1 \mathrm{~Hz}, \mathrm{Ja}, \mathrm{b}=18.0 \mathrm{~Hz}, \mathrm{Ha}) ; 3.76(\mathrm{dd}, 1 \mathrm{H}, \mathrm{Jb}, \mathrm{x}=12.0 \mathrm{~Hz}, \mathrm{Jb}, \mathrm{a}=18.0 \mathrm{~Hz}, \mathrm{Hb}) ; 3.89(\mathrm{t}, 2 \mathrm{H}, \mathrm{J}=6.6 \mathrm{~Hz}$, -OCH2-); 5.35 (dd, 1H, Jx,a = 5.1 Hz, Jx,b=12.0 Hz, Hx); 6.47 (sl, 2H, NH), 6.82-7.79 (m, 9H). 13C NMR (75 MHz, DMSO-d6) $\delta$ (ppm): 14.3-31.7 (Caliphatic); 42.7; 59.6; 67.8 (-OCH2-); 114.8-135.9 (Caromatic); $150.9(\mathrm{C}=\mathrm{N}) ; 155.3(\mathrm{C}=\mathrm{O}) ; 158.1$.

5-(4-(decyloxy)phenyl)-3-(4-fluorophenyl)-4,5-dihydropyrazole-1-carboxamide (18). Yield: 22\%; mp: 109.2-113.0 ${ }^{\circ} \mathrm{C}$; $1 \mathrm{H}$ NMR (300 MHz, DMSO-d $\left.\neg 6\right) \delta(\mathrm{ppm}): 0.82(\mathrm{t}, 3 \mathrm{H}, \mathrm{J}=6.0 \mathrm{~Hz}, \mathrm{CH} 3) ; 1.21-1.67(\mathrm{~m}, 16 \mathrm{H}$, -CH2-); 3.00 (dd, 1H, Ja, $=5.1 \mathrm{~Hz}, \mathrm{Ja}, \mathrm{b}=17.7 \mathrm{~Hz}, \mathrm{Ha}) ; 3.70-3.89$ (m, 3H, Hb, CH2); 5.35 (dd, 1H, Jx,a = 5.1 Hz, $\mathrm{Jx}, \mathrm{b}=12.0 \mathrm{~Hz}, \mathrm{Hx}) ; 6.50$ (sl, 2H, NH); 6.81-7.84 (m, 8H). 13C NMR (75 MHz, DMSO-d6) $\delta$ (ppm): 13.9-31.3 (Caliphatic); 42.3; 59.3; 67.4 (-OCH2-); 114,3-135.4 (Caromatic); $149.6(\mathrm{C}=\mathrm{N}) ; 154.9(\mathrm{C}=\mathrm{O}) ; 157.7 ; 162.9$ (d, $1 \mathrm{~J}=246.0 \mathrm{~Hz})$.

3-(4-fluorophenyl)-4,5-dihydro-5-p-tolylpyrazole-1-carboxamide (19). Yield: 13\%; mp: 151.0-153.0 ${ }^{\circ} \mathrm{C} ; 1 \mathrm{H}$ NMR (300 MHz, DMSO-d6) $\delta$ (ppm): 2.25 (s, 3H, CH3); 3.02 (dd, 1H, Ja,x=5.1 Hz, Ja,b = 18.0 Hz, Ha); 3.76 (dd, $1 \mathrm{H}, \mathrm{Jb}, \mathrm{x}=12.0 \mathrm{~Hz}, \mathrm{Jb}, \mathrm{a}=18.0 \mathrm{~Hz}, \mathrm{Hb}) ; 5.36(\mathrm{dd}, 1 \mathrm{H}, \mathrm{Jx}, \mathrm{a}=5.1 \mathrm{~Hz}, \mathrm{Jx}, \mathrm{b}=12.0 \mathrm{~Hz}, \mathrm{Hx}) ; 6.51(\mathrm{sl}, 2 \mathrm{H}, \mathrm{NH}) ; 7.04-7.12$ $(\mathrm{m}, 4 \mathrm{H}) ; 7.26(\mathrm{t}, 2 \mathrm{H}, \mathrm{J}=8,7 \mathrm{~Hz}) ; 7.81-7.85(\mathrm{~m}, 2 \mathrm{H})$. 13C NMR (75 MHz, DMSO-d6) $\delta(\mathrm{ppm}): 21.0(\mathrm{CH} 3) ; 42.8$; 60.1; 116.0 (d, $2 \mathrm{~J}=21.7 \mathrm{~Hz}) ; 125.8-141.1$ (Caromatic); $150.0(\mathrm{C}=) ; 155.4(\mathrm{C}=\mathrm{O}) ; 163.3(\mathrm{~d}, 1 \mathrm{~J}=246.0 \mathrm{~Hz})$.

5-(4-bromophenyl)-3-(4-fluorophenyl)-4,5-dihydropyrazole-1-carboxamide (20). Yield: 9\%; mp: 176.0-178.0 ${ }^{\circ} \mathrm{C}$; $1 \mathrm{H}$ NMR (300 MHz, DMSO-d6) $\delta(\mathrm{ppm}): 3.07$ (dd, $1 \mathrm{H}, \mathrm{Ja}, \mathrm{x}=5.7 \mathrm{~Hz}, \mathrm{Ja}, \mathrm{b}=18.6 \mathrm{~Hz}, \mathrm{Ha}) ; 3.80(\mathrm{dd}, 1 \mathrm{H}$, $\mathrm{Jb}, \mathrm{x}=12.3 \mathrm{~Hz}, \mathrm{Jb}, \mathrm{a}=18.6 \mathrm{~Hz}, \mathrm{Hb}) ; 5.40(\mathrm{dd}, 1 \mathrm{H}, \mathrm{Jx}, \mathrm{a}=5.7 \mathrm{~Hz}, \mathrm{Jx}, \mathrm{b}=12.3 \mathrm{~Hz}, \mathrm{Hx}) ; 6.58$ (sl, 2H, NH); 7.15 (m, $2 \mathrm{H}) ; 7.28(\mathrm{t}, 2 \mathrm{H}, \mathrm{J}=9.0 \mathrm{~Hz}) ; 7.51(\mathrm{~d}, 2 \mathrm{H}, \mathrm{J}=9.0 \mathrm{~Hz}) ; 7.81-7.86(\mathrm{~m}, 2 \mathrm{H})$. 13C NMR (75 MHz, DMSO-d6) $\delta(\mathrm{ppm})$ : 42.1; 59.4; $115.6(\mathrm{~d}, 2 \mathrm{~J}=21.7 \mathrm{~Hz}) ; 119.9-142.9$ (Caromatic); $149.7(\mathrm{C}=\mathrm{N}) ; 154.9(\mathrm{C}=\mathrm{O}) ; 163.3(\mathrm{~d}, 1 \mathrm{~J}=246.0 \mathrm{~Hz})$.

5-(4-(dimethylamino)phenyl)-3-(4-fluorophenyl)-4,5-dihydropyrazole-1-carboxamide (21). Yield: 17\%; mp: 183.1-185.1 ${ }^{\circ} \mathrm{C}$; $1 \mathrm{H}$ NMR (300 MHz, DMSO-d6) $\delta$ (ppm): $2.82(\mathrm{~s}, 6 \mathrm{H}, \mathrm{CH} 3) ; 3.00(\mathrm{dd}, 1 \mathrm{H}, \mathrm{Ja}, \mathrm{x}=4.8 \mathrm{~Hz}$, $\mathrm{Ja}, \mathrm{b}=17.7 \mathrm{~Hz}, \mathrm{Ha}) ; 3.71(\mathrm{dd}, 1 \mathrm{H}, \mathrm{Jb}, \mathrm{x}=11.4 \mathrm{~Hz}, \mathrm{Jb}, \mathrm{a}=17.7 \mathrm{~Hz}, \mathrm{Hb}) ; 5.29$ (dd, $1 \mathrm{H}, \mathrm{Jx}, \mathrm{a}=4.8 \mathrm{~Hz}, \mathrm{Jx}, \mathrm{b}=11.4 \mathrm{~Hz}$, $\mathrm{Hx}) ; 6.44(\mathrm{sl}, 2 \mathrm{H}, \mathrm{NH}) ; 6.63-7.29(\mathrm{~m}, 4 \mathrm{H}) ; 7.26(\mathrm{t}, 2 \mathrm{H}, \mathrm{J}=9.0 \mathrm{~Hz}) ; 7.80-7.84(\mathrm{~m}, 2 \mathrm{H})$.

5-(4-chlorophenyl)-3-(4-fluorophenyl)-4,5-dihydropyrazole-1-carboxamide (22). Yield: $15 \%$; mp: $149-151^{\circ} \mathrm{C}$; 1H NMR (300 MHz, DMSO-d6) $\delta(\mathrm{ppm}): 3.05$ (dd, 1H, Ja,x =5.4 Hz, Ja,b=18.0 Hz, Ha); $3.79(\mathrm{dd}, 1 \mathrm{H}$, $\mathrm{Jb}, \mathrm{x}=12.6 \mathrm{~Hz}, \mathrm{Jb}, \mathrm{a}=18.0 \mathrm{~Hz}, \mathrm{Hb}) ; 5.40(\mathrm{dd}, 1 \mathrm{H}, \mathrm{Jx}, \mathrm{a}=5.4 \mathrm{~Hz}, \mathrm{Jx}, \mathrm{b}=12.6 \mathrm{~Hz}, \mathrm{Hx}) ; 6.57$ (sl, 2H, NH); 7.18-7.85 (m, $8 \mathrm{H}, \mathrm{Ar})$. 
4,5-dihydro-5-(4-(hexyloxy)phenyl)-3-phenylpyrazole-1-carbothioamide (23). Yield: 29\%; 1H NMR (300 MHz, DMSO-d6) $\delta$ (ppm): 0.84 (sl, 3H, CH3); 1.25-1.67 (m, $8 \mathrm{H},-\mathrm{CH} 2-)$; 3.06-3.12 (m, 1H, Ha); 3.79-3.89 (m, 3H, $\mathrm{Hb},-\mathrm{OCH} 2-)$; 5.83-5.87 (m, 1H, Hx); 6.81-8.01 (m, 11H, Ar e NH). 13C NMR (75 MHz, DMSO-d6) $\delta(\mathrm{ppm})$ : 13.8-30.9 (Caliphatic); 42.3; 62.3; 67.3 (-OCH2-); 114.2-134.8 (Caromatic); $154.9(\mathrm{C}=\mathrm{N}) ; 157.6 ; 176.1(\mathrm{C}=\mathrm{S})$.

4,5-dihydro-5-(4-(octyloxy)phenyl)-3-phenylpyrazole-1-carbothioamide (24). Yield: 27\%; mp: 90.4-92.1 ${ }^{\circ} \mathrm{C}$; $1 \mathrm{H}$ NMR (300 MHz, DMSO-d6) $\delta$ (ppm): 0.83 (sl, 3H, CH3); 1.20-1.67 (m, $12 \mathrm{H},-\mathrm{CH} 2-)$; 3.07-3.13 (m, 1H, $\mathrm{Ha}) ; 3.80-3.90(\mathrm{~m}, 3 \mathrm{H}, \mathrm{Hb},-\mathrm{OCH} 2-) ; 5.86(\mathrm{~m}, 1 \mathrm{H}, \mathrm{Hx}) ; 6.81-8.01(\mathrm{~m}, 11 \mathrm{H}$, Ar e NH). 13C NMR $(75 \mathrm{MHz}$, DMSO-d6) $\delta$ (ppm): 13.8-31.1 (Caliphatic); 42.3; 62.3; 67.3 (-OCH2-); 114.2-134.8 (Caromatic); $154.9(\mathrm{C}=\mathrm{N})$; $157.6 ; 176.1(\mathrm{C}=\mathrm{S})$.

4,5-dihydro-5-(4-(nonyloxy)phenyl)-3-phenylpyrazole-1-carbothioamide (25). Yield: $14 \%$; mp: 86.4-88.2 ${ }^{\circ} \mathrm{C}$; $1 \mathrm{H}$ NMR (300 MHz, DMSO-d6) $\delta$ (ppm): 0.83 (sl, 3H, CH3); 1.22-1.67 (m, $14 \mathrm{H},-\mathrm{CH} 2-) ; 3.09$ (dd, $1 \mathrm{H}$, $\mathrm{Ja}, \mathrm{x}=3.0 \mathrm{~Hz}, \mathrm{Ja}, \mathrm{b}=18.0 \mathrm{~Hz}, \mathrm{Ha}) ; 3.80-3.89(\mathrm{~m}, 3 \mathrm{H}, \mathrm{Hb},-\mathrm{OCH} 2-) ; 5.85$ (dd, $1 \mathrm{H}, \mathrm{Jx}, \mathrm{a}=3.0 \mathrm{~Hz}, \mathrm{Jx}, \mathrm{b}=11.4 \mathrm{~Hz}$, Hx); 6.81-8.02 (m, 11H, Ar e NH). 13C NMR (75 MHz, DMSO-d6) $\delta$ (ppm): 13.9-31.2 (Caliphatic); 42.3; 62.3; 67.3 (-OCH2-); 114.2-134.8 (Caromatic); $154.9(\mathrm{C}=\mathrm{N}) ; 157.6 ; 176.0(\mathrm{C}=\mathrm{S})$.

5-(4-(decyloxy)phenyl)-4,5-dihydro-3-phenylpyrazole-1-carbothioamide (26). Yield: 29\%; mp: 96.2-98.9 ${ }^{\circ} \mathrm{C}$; $1 \mathrm{H}$ NMR (300 MHz, DMSO-d6) $\delta(\mathrm{ppm}): 0.83$ (t, 3H, J =6.9 Hz, CH3); 1.22-1.67 (m, $16 \mathrm{H},-\mathrm{CH} 2-)$; 3.09 (dd, $1 \mathrm{H}, \mathrm{Ja}, \mathrm{x}=3.0 \mathrm{~Hz}, \mathrm{Ja}, \mathrm{b}=18.0 \mathrm{~Hz}, \mathrm{Ha}) ; 3.80-3.90$ (m, 3H, Hb, -OCH2-); 5.85 (dd, $1 \mathrm{H}, \mathrm{Jx}, \mathrm{a}=3.0 \mathrm{~Hz}, \mathrm{Jx}, \mathrm{b}=11.4 \mathrm{~Hz}$, Hx); 6.81-8.00 (m, 11H, Ar e NH). 13C NMR (75 MHz, DMSO-d6) $\delta$ (ppm): 13.8-31.2 (Caliphatic); 42.3; 62.3; 67.3 (-OCH2-); 114.2-134.8 (Caromatic); $154.9(\mathrm{C}=)$; 157.6; $176.1(\mathrm{C}=\mathrm{S})$.

5-(4-(dodecyloxy)phenyl)-4,5-dihydro-3-phenylpyrazole-1-carbothioamide (27). Yield: 22\%; mp: $94.2{ }^{\circ} \mathrm{C}$ $96.3{ }^{\circ} \mathrm{C}$; $1 \mathrm{H}$ NMR (300 MHz, DMSO-d6) $\delta$ (ppm): 0.83 (t, 3H, J=6.0 Hz, CH3); 1.21-1.69 (m, $\left.20 \mathrm{H},-\mathrm{CH} 2-\right)$; 3.09 (dd, $1 \mathrm{H}, \mathrm{Ja}, \mathrm{x}=3.3 \mathrm{~Hz}, \mathrm{Ja}, \mathrm{b}=18.0 \mathrm{~Hz}, \mathrm{Ha}) ; 3.80-3.89(\mathrm{~m}, 3 \mathrm{H}, \mathrm{Hb},-\mathrm{OCH} 2-) ; 5.86$ (dd, 1H, , Jx,a = 3.3 Hz, $\mathrm{Jx}, \mathrm{b}=11.1 \mathrm{~Hz}, \mathrm{Hx}) ; 6.81-8.03(\mathrm{~m}, 11 \mathrm{H}$, Ar e NH). 13C NMR (75 MHz, DMSO-d6) $\delta$ (ppm): 13.9-31.2 (Caliphatic); 42.3; 62.3; 67.3 (-OCH2-); 114.2-134.8 (Caromatic); $154.9(\mathrm{C}=\mathrm{N}) ; 157.6 ; 176.0(\mathrm{C}=\mathrm{S})$.

4,5-dihydro-3-phenyl-5-(4-(tetradecyloxy)phenyl)pyrazole-1-carbothioamide (28). Yield: $37 \%$; mp: 97.0-99.2 ${ }^{\circ} \mathrm{C}$; $1 \mathrm{H}$ NMR (300 MHz, DMSO-d6) $\delta$ (ppm): 0.83 (t, 3H, J =6.9 Hz, CH3); 1.21-1.67 (m, 24 H, -CH2-); 3.12 (dd, $1 \mathrm{H}, \mathrm{Ja}, \mathrm{x}=3.3 \mathrm{~Hz}, \mathrm{Ja}, \mathrm{b}=18.3 \mathrm{~Hz}, \mathrm{Ha}) ; 3.80-3.90$ (m, 3H, Hb, $-\mathrm{OCH} 2-)$; 5.85 (dd, $1 \mathrm{H}, \mathrm{Jx}, \mathrm{a}=3.3 \mathrm{~Hz}, \mathrm{Jx}, \mathrm{b}=11.1 \mathrm{~Hz}$ ); 6.81-8.00 (m, 11H, Ar and NH). 13CNMR (75 MHz, DMSO-d6) $\delta$ (ppm): 13.8-31.2 (Caliphatic); 42.3; 62.3; 67.3 (-OCH2-); 114.2-134.8 (Caromatic); $154.9(\mathrm{C}=\mathrm{N}) ; 157.6 ; 176.1(\mathrm{C}=\mathrm{S})$.

3-(4-fluorophenyl)-4,5-dihydro-5-(4-(nonyloxy)phenyl)pyrazole-1-carbothioamide (29). Yield: 25\%; mp: 113-114 ${ }^{\circ} \mathrm{C}$; $1 \mathrm{H}$ NMR $(300 \mathrm{MHz}$, DMSO-d6) $\delta$ (ppm): 0.81 (t, 3H, J =6.0 Hz, CH3); 1.21-1.65 (m, $14 \mathrm{H},-\mathrm{CH} 2-)$; 3.05-3.11 (m, 1H, Ha); 3.78-3.87 (m, 3H, Hb, -OCH2-); 5.84-5.87 (m, 1H, Hx); 6.80 (d, 4H, J = 9.0 Hz); 7.02 (m, $2 \mathrm{H}) ; 7.27$ (t, 2H, J = 9.0 Hz); 7.89-8.02 (m, 4H, Ar e NH). 13C NMR (75 MHz, DMSO-d6) $\delta(p p m): 13.9-31.3$ (Caliphatic); 42.5; 62.4; $67.3(-\mathrm{OCH} 2-) ; 114.2 ; 115.8(\mathrm{~d}, 2 \mathrm{~J}=21.7 \mathrm{~Hz}) ; 126.6-134.8$ (Caromatic); $154.0(\mathrm{C}=\mathrm{N})$; 157.6; 163.3 (d, $1 \mathrm{~J}=246.7 \mathrm{~Hz}) ; 176.1(\mathrm{C}=\mathrm{S})$.

3-(4-fluorophenyl)-4,5-dihydro-5-(4-(decyloxy)phenyl)pyrazole-1-carbothioamide (30). Yield: 23\%; mp: 105.5-108.4 ${ }^{\circ} \mathrm{C}$; $1 \mathrm{H}$ NMR (300 MHz, DMSO-d6) $\delta(\mathrm{ppm}): 0.82(\mathrm{t}, 3 \mathrm{H}, \mathrm{J}=6.3 \mathrm{~Hz}, \mathrm{CH} 3) ; 1.21-1.67$ (m, 24 $\mathrm{H},-\mathrm{CH} 2-)$; 3.09 (dd, $1 \mathrm{H}, \mathrm{Ha}, \mathrm{Ja}, \mathrm{x}=3.0 \mathrm{~Hz}, \mathrm{Ja}, \mathrm{b}=18.3 \mathrm{~Hz}) ; 3.79-3.89$ (m, 3H, Hb, -OCH2-); 5.85 (dd, $1 \mathrm{H}$, $\mathrm{Jx}, \mathrm{a}=3.0 \mathrm{~Hz}, \mathrm{Jx}, \mathrm{b}=9.9 \mathrm{~Hz}, \mathrm{Hx}) ; 6.80(\mathrm{~d}, 4 \mathrm{H}, \mathrm{J}=8.7 \mathrm{~Hz}) ; 7.03(\mathrm{~m}, 2 \mathrm{H}, \mathrm{J}=8.7 \mathrm{~Hz}) ; 7.28(\mathrm{t}, 2 \mathrm{H}, \mathrm{J}=8.7 \mathrm{~Hz})$; 7.90-8.01 (m, 4H, Ar and NH). 13C NMR (75 MHz, DMSO-d6) $\delta$ (ppm): 13.9-31.2 (Caliphatic); 42.4; 62.4; 67.3 $(-\mathrm{OCH} 2-) ; 114.2 ; 115.7$ (d, $2 \mathrm{~J}=21.5 \mathrm{~Hz}) ; 126.6-134.8$ (Caromatic); $154.0(\mathrm{C}=\mathrm{N}) ; 157.6 ; 163.4(\mathrm{~d}, 1 \mathrm{~J}=247.3 \mathrm{~Hz})$; $176.1(\mathrm{C}=\mathrm{S})$.

3-(4-fluorophenyl)-4,5-dihydro-5-(4-(tetradecyloxy)phenyl)pyrazole-1-carbothioamide (31). Yield: 26\%; mp: 92.2-94.6 ${ }^{\circ} \mathrm{C}$; $1 \mathrm{H}$ NMR (300 MHz, DMSO-d6) $\delta$ (ppm): 0.78 (sl, 3H, CH3); 1.16-1.60 (m, $\left.24 \mathrm{H},-\mathrm{CH} 2-\right)$; 3.00-3.06 (m, 1H, Ha); 3.81 (sl, 3H, Hb, -OCH2-); 5,71-5.86 (m, 1H, Hx); 6.75-8.00 (m, 10H, Ar and NH).

Preparation of pyrazoles derivatives (32-34). The pyrazoles were synthesized according to a previously published procedure ${ }^{36}$. A solution of $0.83 \mathrm{mmol}$ ( 1 eq.) of the respective chalcone in $10 \mathrm{~mL}$ of ethanol, $1.00 \mathrm{mmol}$ (1.2 eq.) of TsNHNH2 and $2 \mathrm{~mol} \%$ iodine was added in a round bottom flask. The mixture was left under magnetic stirring and reflux for $10 \mathrm{~min}$. After that time, $1.25 \mathrm{mmol}$ (1.5 eq.) of $\mathrm{K}_{2} \mathrm{CO}_{3}$ was added to the mixture. The reaction was monitored by TLC (eluent: 100\% DCM, revelator: ultraviolet light and I2 vapor). After completion, the mixture was extracted with ethyl acetate and $5 \% \mathrm{Na}_{2} \mathrm{~S}_{2} \mathrm{O}_{3}$ solution. The organic layer was dried with $\mathrm{Na}_{2} \mathrm{SO}_{4}$ and then filtered and concentrated under reduced pressure. DCM or DCM/hexane were added to the crude and the products were vacuum filtered affording the desired compounds as pure solids. The $1 \mathrm{H}$ NMR spectra of compounds 32-34 are shown in Supplementary Information.

5-(4-fluorophenyl)-3-(4-methylphenyl)-1H-pyrazole (32). Yield: 16\%; m.p.: decomposes at $302{ }^{\circ} \mathrm{C}$; $1 \mathrm{H} \mathrm{NMR}$ (DMSO-d6; $500 \mathrm{MHz}) \delta$ ppm: $13.30(1 \mathrm{H}$, brs, NH), $7.88(2 \mathrm{H}, \mathrm{s}), 7.70(2 \mathrm{H}, \mathrm{s}), 7.26(4 \mathrm{H}, \mathrm{s}), 7.10(1 \mathrm{H}, \mathrm{s}, \mathrm{Hx}) .13 \mathrm{C}$ NMR (DMSO-d6; 125 MHz) $\delta$ ppm: 162.7, 160.8, 150.4, 143.6, 137.6, 130.3, 129.5, 127.1, 126.5, 125.1, 115.6, $115.4,99.2(\mathrm{C}-\mathrm{Hx}), 20.8(\mathrm{CH} 3)$.

3-(4-bromophenyl)-5-(4-fluorophenyl)-1H-pyrazole (33).Yield: 30\%; m.p.: 217-219 ${ }^{\circ} \mathrm{C}$; $1 \mathrm{H} \mathrm{NMR} \mathrm{(DMSO-d6;}$ $500 \mathrm{MHz}) \delta$ ppm: $13.44(1 \mathrm{H}$, brs, NH), 7.85-7.79 $(4 \mathrm{H}, \mathrm{m}), 7.71-7.63(2 \mathrm{H}, \mathrm{m}), 7.31-7.28(2 \mathrm{H}, \mathrm{m}), 7.20(1 \mathrm{H}, \mathrm{s}$, Hx). 13C NMR (DMSO-d6; 125 MHz) $\delta$ ppm: 162.8, 160.9, 150.3, 142.7, 132.8, 131.6, 130.0, 128.4, 127.1, 125.8, $120.5,115.9,115.6,99.9$ (C-Hx).

3-(4-chlorophenyl)-5-(4-fluorophenyl)-1H-pyrazole (34). Yield: 6\%; m.p.: decomposes at $193{ }^{\circ} \mathrm{C}$; $1 \mathrm{H}$ NMR (DMSO-d6; $500 \mathrm{MHz}) \delta$ ppm: 13.43 (1H, brs, NH), 7.87-7.83 (4H, m), 7.54-7.48 (2H, m), 7.33-7.26 (2H, m), 7.20 (1H, s, Hx). 13C NMR (DMSO-d6; $125 \mathrm{MHz}$ ) $\delta$ ppm: 162.9, 160.9, 150.6, 150.2, 142.7, 132.5, 132.0, 129.1, 128.7, 127.3, 126.8, 116.1, 116.0, 115.6, 115.5, 99.9 (C-Hx). 
Drugs, media, and reagents for biological assays. Dulbecco's Modified Eagle Medium (DMEM), Roswell Park Memorial Institute (RPMI) 1640 medium, inactivated fetal bovine serum, and antibiotics (10,000 $\mathrm{U} / \mathrm{mL}$ penicillin G sodium salt, and $10 \mathrm{mg} / \mathrm{mL}$ streptomycin sulfate) were purchased from Atena Biotecnologia (Vitrocell, Campinas, SP, Brazil). Thiazolyl blue tetrazolium bromide (MTT) and dimethyl sulfoxide (DMSO) were obtained from Sigma-Aldrich (St. Louis, MO, USA). Praziquantel was kindly provided by Ecovet Indústria Veterinária Ltda (São Paulo, SP, Brazil). In all procedure, compounds were solubilized in DMSO.

Preparation of parasites and in vitro antischistosomal assay. Adult schistosomes (BH strain) were isolated from infected mice and cultured in RPMI medium $+10 \%$ fetal calf serum and $100 \mathrm{U} / \mathrm{mL}$ penicillin and $100 \mu \mathrm{g} / \mathrm{mL}$ streptomycin in a 24-well culture plate (Corning, New York, NY, USA) containing one pair of parasites per well at $37^{\circ} \mathrm{C}$ and $5 \% \mathrm{CO}_{2}$ (Panasonic Healthcare, Sakata, Oizumi-machi, Japan) ${ }^{38,39}$. For antischistosomal assay, compounds were dissolved in DMSO (final concentration of $0.5 \% \mathrm{v} / \mathrm{v}$ ). Each drug concentration was tested at least in triplicate, and the experiments were repeated three times. The initial concentration of the pyrazolines and praziquantel was $50 \mu \mathrm{M}$ and $3 \mu \mathrm{M}$, respectively, which was serially diluted in medium with twofold dilutions to give six concentrations ${ }^{40,41}$. The negative control worms were assayed in RPMI 1640 medium and RPMI 1640 with $0.5 \%$ DMSO. Parasites were monitored daily at 24,48 and $72 \mathrm{~h}$ under a stereomicroscope (Leica Microsystems EZ4E, Wetzlar, Germany) and an inverted microscope (BEL Engineering INV 100, Monza, MB, Italy). Egg production was evaluated daily as previously described ${ }^{42}$. Parasite viability was averaged and $50 \%$ effective concentrations $\left(\mathrm{EC}_{50}\right)$ were calculated using GraphPad Prism software ${ }^{24,43}$.

Cell culture and cytotoxicity assay. The cytotoxicity of compounds was tested against Vero cells (African green monkey kidney cells obtained from the American Type Culture Collection, ATCC; Manassas, VA, USA) and SH-SY5Y cells (human neuroblastoma obtained from Banco de Células do Rio de Janeiro, BCRJ, RJ, Brazil). Cells was cultured in DMEM medium supplemented with $10 \%$ fetal calf serum, penicillin (100 U/ $\mathrm{mL}$ ) and streptomycin $(100 \mu \mathrm{g} / \mathrm{mL})$ and $2 \mathrm{mM}$ of L-glutamine at $37^{\circ} \mathrm{C}$ and in a $5 \% \mathrm{CO}_{2}$ humidified incubator (Panasonic). The DMEM contained 1 or $4 \mathrm{mg} / \mathrm{mL}$ glucose for Vero and SH-SY5Y cells, respectively. Cytotoxicity assay was performed as previously described ${ }^{25,26}$. Briefly, cells were seeded in 96 -well plates (Corning) in DMEM medium and incubated with twofold serial drug starting at $200 \mu \mathrm{M}$ following a $24 \mathrm{~h}$ adhesion period at $37^{\circ} \mathrm{C}$ in $5 \% \mathrm{CO}_{2}$. After $72 \mathrm{~h}$, MTT was added and incubation was continued for another $3 \mathrm{~h}$. The plate was then read using spectrophotometer (Epoch Microplate Spectrophotometer, BioTek Instruments, Winooski, VT, USA) at $595 \mathrm{~nm}$. The assay was conducted in duplicate and repeated three times. Values were expressed as percentage of the control and $50 \%$ cytotoxic concentration $\left(\mathrm{CC}_{50}\right)$ values were calculated ${ }^{27}$. The selectivity indices (SI) of tested compounds were calculated by dividing $\mathrm{CC}_{50}$ values obtained on mammalian cells with $\mathrm{EC}_{50}$ values determined on S. mansoni $i^{44}$.

In silico studies and drug-likeness assessment. Physicochemical descriptors as well as prediction of pharmacokinetic parameters, druglike nature and medicinal chemistry friendliness of compounds 16, 18, 19, 21, 22 and 23 were obtained using the webserver SwissADME ${ }^{45}$. Drug-likeness with filters including Lipinski (Pfizer), Veber (GSK), Muegge (Bayer), Egan (Pharmacia), and Ghose (Amgen) were performed using the same webserver.

Ethical approval. The study was conducted according to the guidelines of Animal Ethics and approved by the Committee for the Ethical Use of Animals in Experimentation of Guarulhos University (São Paulo, Brazil) according to Brazilian law (protocol code 31/17, approved on 20 March 2017).

Received: 27 September 2021; Accepted: 17 November 2021

Published online: 06 December 2021

\section{References}

1. McManus, D. P. et al. Schistosomiasis. Nat. Rev. Dis. Primers 4, 30093684. https://doi.org/10.1038/s41572-018-0013-8 (2018),

2. Colley, D. G., Bustinduy, A. L., Secor, W. E. \& King, C. H. Human schistosomiasis. Lancet 383, 2253-2264. https://doi.org/10.1016/ S0140-6736(13)61949-2 (2014).

3. World Health Organization. Schistosomiasis (2021). https://www.who.int/news-room/fact-sheets/detail/schistosomiasis.

4. Mawa, P. A., Kincaid-Smith, J., Tukahebwa, E. M., Webster, J. P. \& Wilson, S. Schistosomiasis morbidity hotspots: Roles of the human host, the parasite and their interface in the development of severe morbidity. Front. Immunol. 12, 635869. https://doi.org/ 10.3389/fimmu.2021.635869 (2021).

5. Wiegand, R. E. et al. A persistent hotspot of Schistosoma mansoni infection in a five-year randomized trial of praziquantel preventative chemotherapy strategies. J. Infect. Dis. 216, 1425-1433. https://doi.org/10.1093/infdis/jix496 (2017).

6. Deol, A. K. et al. Schistosomiasis-Assessing progress toward the 2020 and 2025 global goals. N. Engl. J. Med. 381, 2519-2528. https://doi.org/10.1056/NEJMoa1812165 (2019).

7. Assaré, R. K. et al. Characteristics of persistent hotspots of Schistosoma mansoni in western Côte d'Ivoire. Parasit Vectors 13, 337. https://doi.org/10.1186/s13071-020-04188-x (2020).

8. Kabuyaya, M., Chimbari, M. J. \& Mukaratirwa, S. Efficacy of praziquantel treatment regimens in pre-school and school aged children infected with schistosomiasis in sub-Saharan Africa: A systematic review. Infect. Dis. Poverty 7, 1-7. https://doi.org/10. 1186/s40249-018-0448-x (2018).

9. Chelladurai, J. J., Kifleyohannes, T., Scott, J. \& Brewer, M. T. Praziquantel resistance in the zoonotic cestode Dipylidium caninum. Am. J. Trop. Med. Hyg. 99, 1201-1205. https://doi.org/10.4269/ajtmh.18-0533 (2018). 
10. Mafud, A. C., Ferreira, L. G., Mascarenhas, Y. P., Andricopulo, A. D. \& de Moraes, J. Discovery of novel antischistosomal agents by molecular modeling approaches. Trends Parasitol. 32, 874-886. https://doi.org/10.1016/j.pt.2016.08.002 (2016).

11. Lago, E. M. et al. Antischistosomal agents: State of art and perspectives. Future Med. Chem. 10, 89-120. https://doi.org/10.4155/ fmc-2017-0112 (2018).

12. Vitaku, E., Smith, D. T. \& Njardarson, J. T. Analysis of the structural diversity, substitution patterns, and frequency of nitrogen heterocycles among U.S. FDA approved pharmaceuticals. J. Med. Chem. 57, 10257-10274. https://doi.org/10.1021/jm501100b (2014).

13. de Moraes, J. \& Geary, T. G. FDA-Approved antiparasitic drugs in the 21st century: A success for helminthiasis?. Trends Parasitol. 36, 573-575. https://doi.org/10.1016/j.pt.2020.04.005 (2020).

14. Rando, D. G. G. et al. Vanillin-related N-acylhydrazones: Synthesis, antischistosomal properties and target fishing studies. Curr. Top. Med. Chem. 19, 1241-1251. https://doi.org/10.2174/1568026619666190620163237 (2019).

15. Amorim, C. R. et al. Schiff bases of 4-Phenyl-2-Aminothiazoles as hits to new antischistosomal: Synthesis, in vitro, in vitro and in silico studies. Eur. J. Pharm. Sci. 150, 105371. https://doi.org/10.1016/j.ejps.2020.105371 (2020).

16. Havrylyuk, D., Roman, O. \& Lesyk, R. Synthetic approaches, structure activity relationship and biological applications for pharmacologically attractive pyrazole/pyrazoline-thiazolidine-based hybrids. Eur. J. Med. Chem. 113, 145-166. https://doi.org/10. 1016/j.ejmech.2016.02.030 (2016).

17. Kumar, G. et al. Pyrazole-pyrazoline as promising novel antimalarial agents: A mechanistic study. Eur. J. Med. Chem. 149, 139-147. https://doi.org/10.1016/j.ejmech.2018.01.082 (2018).

18. Matiadis, D. et al. Pyrazol(in)e derivatives of curcumin analogs as a new class of anti-Trypanosoma cruzi agents. Future Med. Chem. 13, 701-714. https://doi.org/10.4155/fmc-2020-0349 (2021).

19. de Moraes, J. Natural products with antischistosomal activity. Future Med. Chem. 7, 801-820. https://doi.org/10.4155/fmc.15.23 (2015).

20. Pink, R., Hudson, A., Mouriès, M. A. \& Bendig, M. Opportunities and challenges in antiparasitic drug discovery. Nat. Ver. Drug Discov. 4, 727-740. https://doi.org/10.1038/nrd1824 (2005).

21. Patra, M. et al. Ferrocenyl derivatives of the anthelmintic praziquantel: Design, synthesis, and biological evaluation. J. Med. Chem. 55, 8790-8798. https://doi.org/10.1021/jm301077m (2012).

22. Mayoka, G., Keiser, J., Häberli, C. \& Chibale, K. Structure-activity relationship and in vitro absorption, distribution, metabolism, excretion, and toxicity (ADMET) studies of $\mathrm{N}$-aryl 3-trifluoromethyl pyrido[1,2-a]benzimidazoles that are efficacious in a mouse model of schistosomiasis. ACS Infect. Dis. 5, 418-429. https://doi.org/10.1021/acsinfecdis.8b00313 (2019).

23. Menezes, C. M. et al. Synthesis, biological evaluation, and structure-activity relationship of clonazepam, meclonazepam, and 1,4-benzodiazepine compounds with schistosomicidal activity. Chem. Biol. Drug Des. 79, 943-949. https://doi.org/10.1111/j. 1747-0285.2012.01354.x (2012).

24. Roquini, D. B. et al. Promethazine exhibits antiparasitic properties in vitro and reduces worm burden, egg production, hepato-, and splenomegaly in a schistosomiasis animal model. Antimicrob. Agents Chemother. 63, e01208-e1219. https://doi.org/10.1128/ AAC.01208-19 (2019).

25. Sessa, D. P. et al. 15ß-Senecioyl-oxy-ent-kaur-16-en-19-oic acid, a diterpene isolated from Baccharis lateralis, as promising oral compound for the treatment of schistosomiasis. J. Nat. Prod. 83, 3744-3750. https://doi.org/10.1021/acs.jnatprod.0c01050 (2020).

26. Dematei, A. et al. Mechanistic insights into the leishmanicidal and bactericidal activities of batroxicidin, a cathelicidin-related peptide from a south american viper (Bothrops atrox). J. Nat. Prod. 84, 1787-1798. https://doi.org/10.1021/acs.jnatprod.1c00153 (2021).

27. de Brito, M. G. et al. Therapeutic effect of diminazene aceturate on parasitic blood fluke Schistosoma mansoni infection. Antimicrob. Agents Chemother. 64, e01372-e1420. https://doi.org/10.1128/AAC.01372-20 (2020).

28. Baell, J. B. \& Holloway, G. A. New substructure filters for removal of pan assay interference compounds (PAINS) from screening libraries and for their exclusion in bioassays. J. Med. Chem. 53, 2719-2740. https://doi.org/10.1021/jm901137j (2010).

29. Brenk, R. et al. Lessons learnt from assembling screening libraries for drug discovery for neglected diseases. ChemMedChem 3, 435-444. https://doi.org/10.1002/cmdc.200700139 (2008).

30. Struble, T. J. et al. Current and future roles of artificial intelligence in medicinal chemistry synthesis. J. Med. Chem. 63, 8667-8682. https://doi.org/10.1021/acs.jmedchem.9b02120 (2020).

31. Lipinski, C. A., Lombardo, F., Dominy, B. W. \& Feeney, P. J. Experimental and computational approaches to estimate solubility and permeability in drug discovery and development settings. Adv. Drug Deliv. Rev. 46, 3-26. https://doi.org/10.1016/s0169-409x(00) 00129-0 (2001).

32. Veber, D. F. et al. Molecular properties that influence the oral bioavailability of drug candidates. J. Med. Chem. 45, 2615-2623. https://doi.org/10.1021/jm020017n (2002).

33. Egan, W. J., Merz, K. M. \& Baldwin, J. J. Prediction of drug absorption using multivariate statistics. J. Med. Chem. 43, 3867-3877. https://doi.org/10.1021/jm000292e (2000).

34. Muegge, I., Heald, S. L. \& Brittelli, D. Simple selection criteria for drug-like chemical matter. J. Med. Chem. 44, 1841-1846. https:// doi.org/10.1021/jm015507e (2001).

35. Ghose, A. K., Viswanadhan, V. N. \& Wendoloski, J. J. A knowledge-based approach in designing combinatorial or medicinal chemistry libraries for drug discovery. 1. A qualitative and quantitative characterization of known drug databases. J. Comb. Chem. 1, 55-68. https://doi.org/10.1021/cc9800071 (1999).

36. Enes, K. B. et al. Synthesis and theoretical study of a series of 3,5-disubstitutes pyrazoles. Lett. Org. Chem. 17, 932-938. https:// doi.org/10.2174/1570178617666200409095632 (2020).

37. Miguel, F. B. et al. Synthesis, spectroscopic and computational characterization of the tautomerism of pyrazoline derivatives from chalcones. Spectrochim. Acta A Mol. Biomol. Spectrosc. 152, 318-326. https://doi.org/10.1016/j.saa.2015.07.041 (2016).

38. Lago, E. M. et al. Phenotypic screening of nonsteroidal anti-inflammatory drugs identified mefenamic acid as a drug for the treatment of schistosomiasis. EBioMedicine 43, 370-379. https://doi.org/10.1016/j.ebiom.2019.04.029 (2019).

39. Porto, R. et al. Antiparasitic properties of cardiovascular agents against human intravascular parasite Schistosoma mansoni. Pharmaceuticals (Basel) 14, 686. https://doi.org/10.3390/ph14070686 (2021).

40. Silva, T. C. et al. New evidence for tamoxifen as an antischistosomal agent: In vitro, in vitro and target fishing studies. Future Med. Chem. 13, 945-957. https://doi.org/10.4155/fmc-2020-0311 (2021).

41. Xavier, R. P. et al. H1-antihistamines as antischistosomal drugs: In vitro and in vitro studies. Parasit Vectors 13, 278. https://doi. org/10.1186/s13071-020-04140-z (2020).

42. Silva, M. P. et al. Brazilian red propolis exhibits antiparasitic properties in vitro and reduces worm burden and egg production in an mouse model harboring either early or chronic Schistosoma mansoni infection. J. Ethnopharmacol. 264, 113387. https://doi. org/10.1016/j.jep.2020.113387 (2021).

43. Guerra, R. A. et al. In vitro and in vitro studies of spironolactone as an a antischistosomal drug capable of clinical repurposing. Antimicrob. Agents Chemother. 63, e01722-e1818. https://doi.org/10.1128/AAC.01722-18 (2019).

44. Mengarda, A. C. et al. Licarin A, a neolignan isolated from Nectandra oppositifolia Nees \& Mart. (Lauraceae), exhibited moderate preclinical efficacy against Schistosoma mansoni infection. Phytother. Res. 35, 5154-5162. https://doi.org/10.1002/ptr.7184 (2021).

45. Daina, A., Michielin, O. \& Zoete, V. Swiss ADME: A free web tool to evaluate pharmacokinetics, drug-likeness and medicinal chemistry friendliness of small molecules. Sci. Rep. 7, 1-13. https://doi.org/10.1038/srep42717 (2017). 


\section{Acknowledgements}

This research was funded by Conselho Nacional de Desenvolvimento Científico e Tecnológico (CNPq, Chamada Universal 2018), grant number 408581/2018-2 to J.d.M. The funder had no role in study design, data collection and interpretation, or the decision to submit the work for publication. We thank Dr Bianca C. Silva and Dr Rayssa A. Cajas for support during in vitro studies with S. mansoni at Núcleo de Pesquisa em Doenças Negligenciadas, Universidade Guarulhos (Guarulhos, SP, Brazil). We are also grateful to Dra Suzana A. Z. Lescano (Instituto de Medicina Tropical, Universidade de São Paulo, São Paulo, SP, Brazil) and Dra Maria Cristina Conceição Melo (Faculdade de Medicina, Universidade São Paulo, São Paulo, SP, Brazil) for support during studies with S. mansoni. A.C.M. was supported by a fellowship from the Fundação de Amparo à Pesquisa do Estado de São Paulo (FAPESP, grant 2019/25905-2). C.S.M. and F.B.M. were supported by a fellowship from the Coordenação de Aperfeiçoamento de Pessoal de Nível Superior (CAPES). J.d.M. also received established investigator fellowship from CNPq. M.R.C.C. thanks CNPq (EDITAL MCTI/CNPq No: 14/2014) for grant.

\section{Author contributions}

C.S.M. and J.d.M. carried out the conceptualization of the study; C.S.M., A.C.M., F.B.M., K.B.E., and V.C.R. contributed to development of methodology; A.C.M. and P.W. performed calculations in the software; A.C.M and V.C.R. carried out the validation; C.S.M., A.C.M., M.R.C.C. and J.M. carried out the formal analysis; C.S.M., A.C.M., F.B.M., K.B.E., V.C.R. and P.W. contributed in the investigation phase; J.d.M., M.C.C.E.S. and M.R.C.C. contributed with resources; A.C.M., M.R.C.C. and P.W. carried out data curation; M.R.C.C. and J.d.M wrote original draft, reviewed and edited the final version; C.S.M., A.C.M., F.B.M., K.B.E., V.C.R., M.C.C.E.S., A.S., P.W., M.R.C.C. and J.d.M. contributed to visualization; A.C.M. contributed to supervision; J.d.M. carried out project administration; M.R.C.C. and J.d.M contributed to funding acquisition. All authors have read and agreed to the published version of the manuscript.

\section{Competing interests}

The authors declare no competing interests.

\section{Additional information}

Supplementary Information The online version contains supplementary material available at https://doi.org/ 10.1038/s41598-021-02792-0.

Correspondence and requests for materials should be addressed to P.W., M.R.C.C. or J.d.M.

Reprints and permissions information is available at www.nature.com/reprints.

Publisher's note Springer Nature remains neutral with regard to jurisdictional claims in published maps and institutional affiliations.

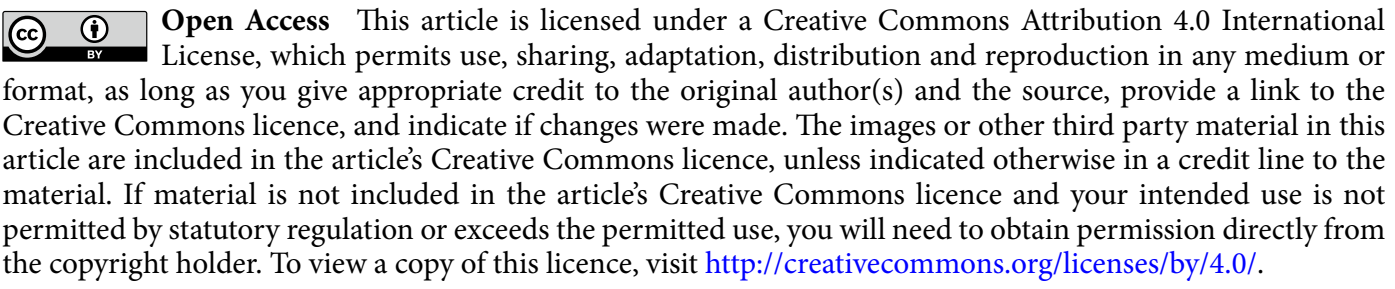

(C) The Author(s) 2021 